\title{
Mode and Tempo of Tangential Cell Migration in the Cerebellar External Granular Layer
}

\author{
Hitoshi Komuro, ${ }^{1,2}$ Ellada Yacubova, ${ }^{1}$ Elina Yacubova, ${ }^{1}$ and Pasko Rakic ${ }^{2}$ \\ ${ }^{1}$ Department of Neurosciences, Lerner Research Institute, The Cleveland Clinic Foundation, Cleveland, Ohio 44195, and \\ 2Section of Neurobiology, Yale University School of Medicine, New Haven, Connecticut 06510
}

\begin{abstract}
After their final mitosis, cerebellar granule cells remain in the external granular layer (EGL) for 20-48 hr before initiating their radial migration across the molecular layer $(\mathrm{ML})$, but the significance of this latent period is not well understood. In the present study, we used a confocal microscope to examine morphogenetic changes and behavior of postmitotic granule cells restricted to the EGL in slice preparations of the postnatal mouse cerebellum. We found that, coincident with the extension of two uneven horizontal processes oriented parallel to the longitudinal axis of the folium, postmitotic granule cells start to migrate tangentially in the direction of the larger process. Interestingly, their morphology and the speed of cell movement change systematically with their position within the EGL. The rate of tangential cell movement is fastest $(\sim 14.8 \mu \mathrm{m} / \mathrm{hr})$ in the middle of the EGL, when cells have two short horizontal processes. As granule cells elongate their somata and extend
\end{abstract}

Morphological transformation and translocation of cerebellar granule cells within the external granular layer (EGL) offer an opportunity to study the basic mechanisms of neuronal migration and differentiation. This secondary proliferative layer originates at the lateral aspect of the rhombencephalon (rhombic lip by His, 1890) and spreads quickly over the entire surface of the cerebellar hemispheres during the prenatal development (for review, see Sidman and Rakic, 1982; Rakic, 1985). Early studies using ${ }^{3} \mathrm{H}-$ thymidine labeling have confirmed the general concept, proposed by Ramon y Cajal (1911), that cerebellar granule cells originate in the EGL and, after their final cell division, migrate radially across the molecular layer $(\mathrm{ML})$ to the internal granular layer (IGL) where they reside in the adult cerebellum (Miale and Sidman, 1961; Fujita et al., 1966; Fujita, 1967). Combined application of electron microscopy, Golgi-impregnation method, and ${ }^{3} \mathrm{H}-$ thymidine autoradiography indicated that postmitotic granule cells remain in the EGL for $>20 \mathrm{hr}$ as they form, in succession, three cytoplasmic processes that change the shape of the cell from round to bipolar and then to the three-polar form (Rakic, 1971, 1972, 1973). More recently, the use of replication-incompetent retrovirus suggests that granule cells may migrate tangentially in both rostrocaudal and mediolateral planes before onset of their radial migration (Ryder and Cepko, 1994).

\footnotetext{
Received Aug. 14, 2000; revised Oct. 6, 2000; accepted Oct. 19, 2000.

This work was supported by the United States Public Health Service (P.R) and the Cleveland Clinic Foundation (H.K). We thank Dr. K. Wikler for his useful suggestions and comments on this manuscript.

Correspondence should be addressed to Dr. Hitoshi Komuro, Department of Neurosciences/NC30, Lerner Research Institute, The Cleveland Clinic Foundation, 9500 Euclid Avenue, Cleveland, OH 44195. E-mail: komuroh@ccf.org.

Copyright (C) 2001 Society for Neuroscience 0270-6474/01/210527-14\$15.00/0
}

longer horizontal processes at the bottom of the EGL, they move at a reduced rate $(\sim 12.6 \mu \mathrm{m} / \mathrm{hr})$. At the interface of the EGL and ML where cells migrate tangentially at the slowest rate $(\sim 4.1 \mu \mathrm{m} / \mathrm{hr})$, their somata round and then begin to extend couples of the descending processes into the ML. After the stationary period, granule cells abruptly extend a single vertical process and initiate the transition from tangential to radial migration, reshaping their rounded somata into a vertically elongated spindle. These observations suggest that tangential migration of granule cells within the EGL may provide the developmental mechanisms for their appropriate allocation across parasagittal compartments of the expanding cerebellar cortex.

Key words: cerebellar development; granule cell; neuronal cell migration; confocal microscopy; brain slice preparation; fluorescent carbocyanine dye; rate of cell movement
Although radial migration of granule cells along the Bergmann glial processes in the ML have been extensively analyzed (for review, see Rakic, 1981, 1990; Hatten and Mason, 1990), little is known about the early behavior of postmitotic granule cells within the EGL before they start their descent to the ML. Yet, the tangential movement within the EGL is critical to understanding how cerebellar compartments form, as well as how clonally related cells become allocated to the IGL in the expanded cerebellar hemispheres. This is an important issue because, after radial migration begins, the granule cells cannot change any more than their mediolateral or anteroposterior position (Komuro and Rakic, 1998a). During early development, the cerebellum expresses distinct, stripe-like compartments as revealed by the expression of specific genes and molecules, containing candidate molecules that may generate attractive or repulsive signals to migrating cells (Hawkes and Leclerc, 1987; Herrup and Kuemerle, 1997; Lin and Cepko, 1998; Ozol et al., 1999; Alcantara et al., 2000). The differential expression of various spatial cues raises the possibility that postmitotic granule cells may migrate within the EGL to find their assigned position in appropriate compartments before establishing their contact with Bergmann glial fibers that will carry them to the IGL.

A major impediment in the analysis of granule cell behavior in the EGL was the availability of a reliable assay system. For example, the use of ${ }^{3} \mathrm{H}$-thymidine labeling alone could not reveal the extent, direction, and rate of cell migration within a histologically homogeneous cell layer such as the EGL. Moreover, dissociated cells and microexplant culture systems do not retain the ambient cellular environment and cytoarchitecture of the living cerebellum. However, the development of acute slice preparation 


\section{A}

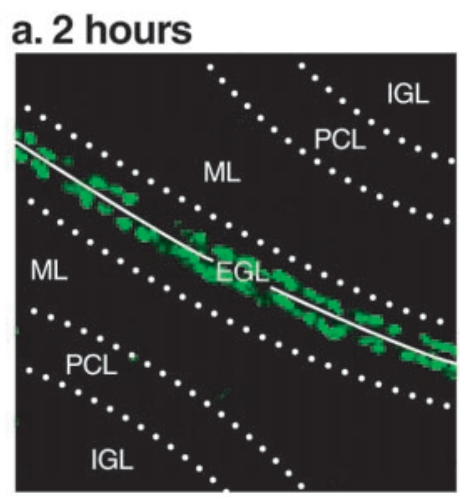

\section{b. 1 day}
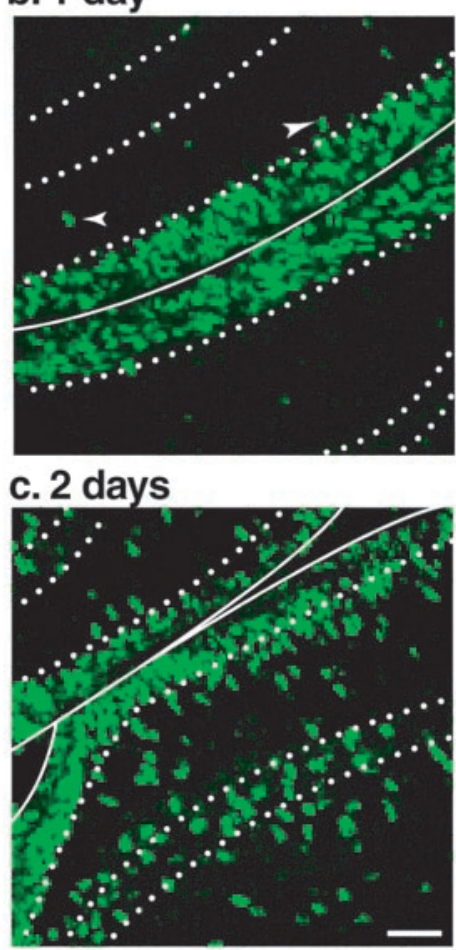

B

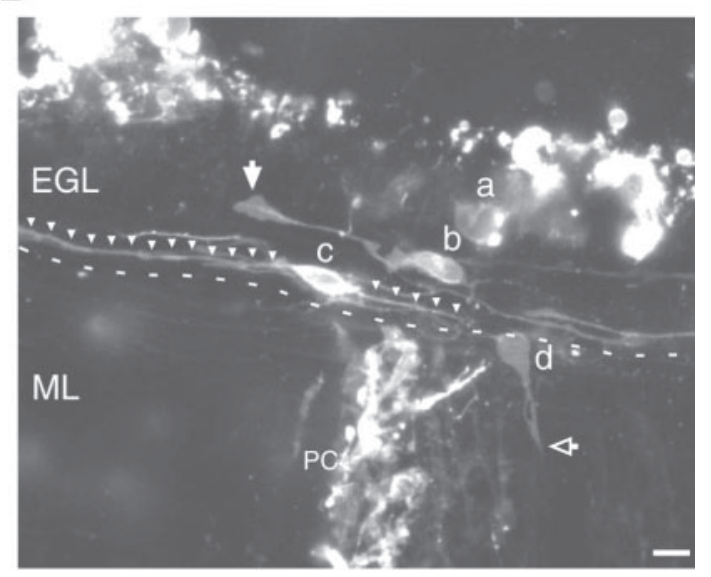

Figure 1. A, Time course of translocation of postmitotic granule cells in the EGL. P10 mice were injected with BrdU intraperitoneally and killed 2 $\mathrm{hr}(a), 1 \mathrm{~d}(b)$, and $2 \mathrm{~d}(c)$ later. Two hours after injection, BrdU-labeled cells were localized at the top level of the EGL. One day after injection, the BrdU-labeled cells occupied the entire EGL. Two days after injection, approximately half of BrdU-labeled cells left the EGL and translocated to the ML, PCL, and IGL. B, Morphology of granule cell precursors and postmitotic granule cells in the EGL of P10 mouse cerebellum. The granule cells in the EGL at the pyramis were visualized $2 \mathrm{hr}$ after DiI (for a description of the method, see Komuro and Rakic, 1999) allows direct observation of the granule cell movement within its natural cellular milieu (Komuro and Rakic, 1992, 1993, 1995, 1998a,b). The study of granule cell behavior in real time demonstrates that, at the various levels of the EGL, postmitotic granule cells exhibit a different morphology and rate of tangential movement before the onset of radial migration that sets the site of its journey to the final destination.

\section{MATERIALS AND METHODS}

Cerebellar slice preparations. Postnatal day 10 (P10) mice (CD-1) were killed by decapitation, in accordance with institutional guidelines. Cerebella were quickly removed from the skull and placed in cold $\left(5^{\circ} \mathrm{C}\right) \mathrm{HBSS}$. Before cutting, cerebella were embedded in $20 \%$ gelatin and sectioned transversely or sagittally into $300-$ to $400-\mu \mathrm{m}$-thick slices on a vibrating blade microtome (VT1000S; Leica, Nussloch, Germany). After sectioning, pia mater and gelatin were carefully removed under a dissecting microscope.

1,1'-Dioctadecyl-3,3,3',3'-tetramethylindocarbocyanine perchlorate labeling. To label granule cells in the EGL, cerebellar slices were incubated for $3 \mathrm{~min}$ at room temperature in a fluorescent lipophilic carbocyanine dye [1,1'-dioctadecyl-3,3,3',3'-tetramethylindocarbocyanine perchlorate (DiI)] $(7.2 \mu \mathrm{g} / \mathrm{ml})$ (Molecular Probes, Eugene, OR), which was added to the cell culture medium (Honig and Hume, 1986). The incubation medium consisted of minimum essential medium (Life Technologies, Rockville, MD) supplemented with $40 \mathrm{~mm}$ glucose, $1.8 \mathrm{~mm}$ glutamine, $24 \mathrm{~mm} \mathrm{NaHCO}{ }_{3}$, penicillin $(90 \mathrm{U} / \mathrm{ml})$, and streptomycin $(90 \mu \mathrm{g} / \mathrm{ml})$. After rinsing in the incubation medium, brain slices were maintained in an incubator $\left(37^{\circ} \mathrm{C}\right.$, $95 \% \mathrm{O}_{2}-5 \% \mathrm{CO}_{2}$ ) for an additional $2 \mathrm{hr}$ to allow diff usion of DiI molecules in the plasma membrane of the granule cells. Slices were then transferred into the chamber of a microincubator (PDMI-2; Medical Systems Corp., Greenvale, NY) attached to the stage of an inverted microscope (DM IRBE; Leica). The rate of cell movement is closely related to the temperature of the medium; lowering the medium temperature slows cell movement (Rakic and Komuro, 1995). Therefore, the chamber temperature was kept at $37.0 \pm 0.5^{\circ} \mathrm{C}$ using a temperature controller (TC-202; Medical Systems Corp.), and the slices were provided with constant gas flow (95\% $\mathrm{O}_{2}-5 \%\left(\mathrm{CO}_{2}\right)$. To prevent movement of the slice preparation during observation, a nylon net glued to a small silver wire ring was placed over the preparations.

Observation of granule cell migration. A laser scanning confocal microscope (TCS SP; Leica) was used to visualize migrating granule cells labeled with DiI in the slices (Komuro and Rakic, 1995, 1998a; Rakic and Komuro, 1995). The use of this microscope permitted high-resolution imaging of migrating neurons up to $120 \mu \mathrm{m}$ deep within the tissue slices. The tissue was illuminated with a $488 \mathrm{~nm}$ wavelength light from an argon laser through an epifluorescence inverted microscope equipped with a $40 \times$ oil-immersion objective (numerical aperture 1.25; Leica), and fluorescence emission was detected at $530 \pm 15 \mathrm{~nm}$. To clearly resolve movement of migrating cells, image data typically were collected at an additional electronical zoom factor of 1.5-3. Time-lapse imaging of live, fluorescently labeled cells can produce phototoxic effects in the imaged cells. Indeed, when well stained cells were imaged with very high incident illumination intensity or were imaged too frequently, we invariably saw changes in the structure or dynamics of the migrating granule cells. However, when the incident illumination was sufficiently attenuated, the labeled specimens could be imaged (5 min intervals) for many hours without signs of photodynamic damage (Komuro and Rakic, 1995, 1998a). To protect the migrating granule cells labeled with DiI from any cytotoxic effect of the laser beam, the excitation light level was reduced by $99 \%$. To avoid injured granule cells located near the sectioning surfaces, we examined the shape and behavior of migrating granule cells located $15-50 \mu \mathrm{m}$ below the surface of the slices. If granule cells showed no evidence of changes in cell shape or motility for $>300 \mathrm{~min}$, the brain slice was discarded. Shock to the tissue during sectioning of slices can disrupt cell movement and prevent cells from migrating. Accordingly, the present study is based on the analysis of approximately one-half of the healthy slices that had displayed

$\leftarrow$

staining. The granule cell precursor $(a)$ had a round soma without any long processes. Postmitotic granule cells $(b, c)$ had spindle-shaped cell bodies oriented parallel to the longitudinal axis of the folium with two horizontal processes. On the EGL-ML border, the postmitotic granule cell $(d)$ had a rounded cell body with vertically oriented short processes penetrating the ML. Scale bars, $10 \mu \mathrm{m}$. PC, Purkinje cell. 
A
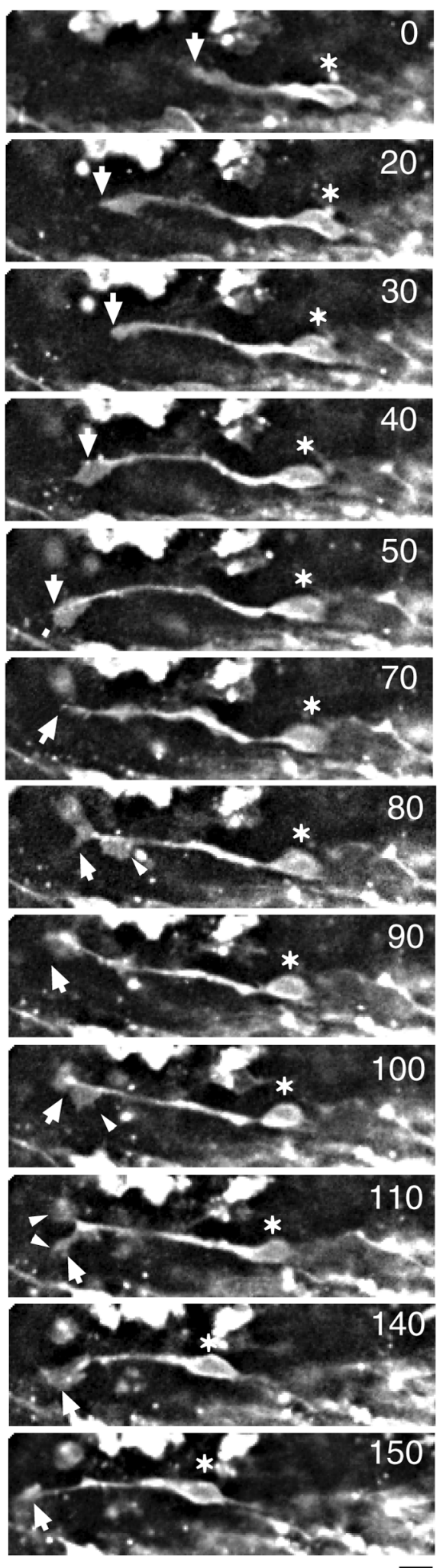

B

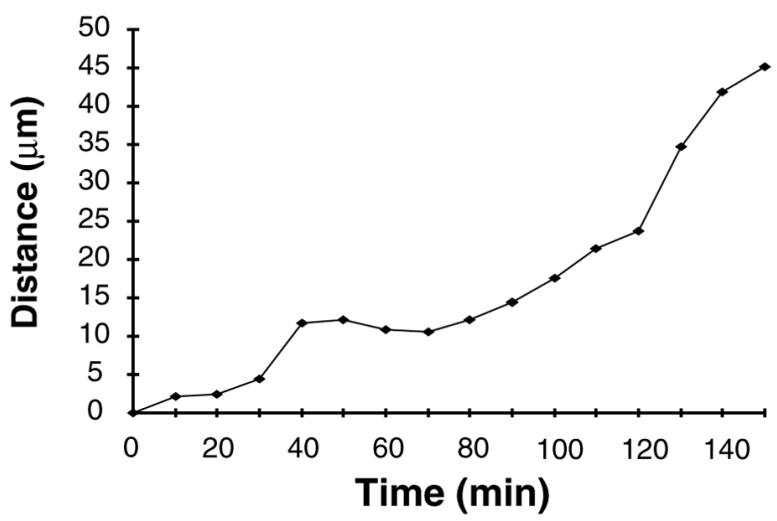

C

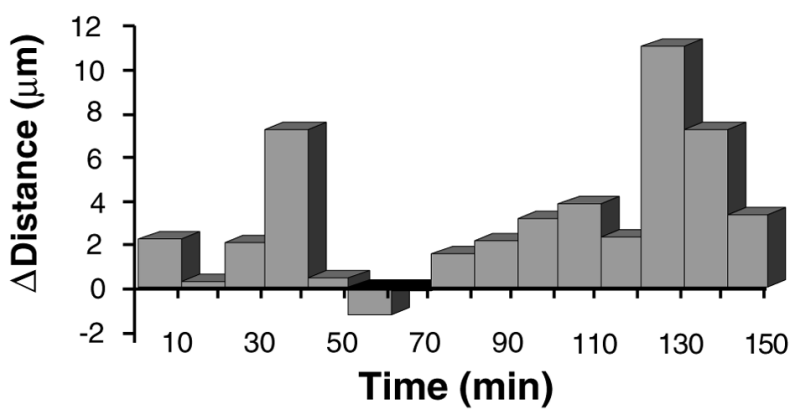

D

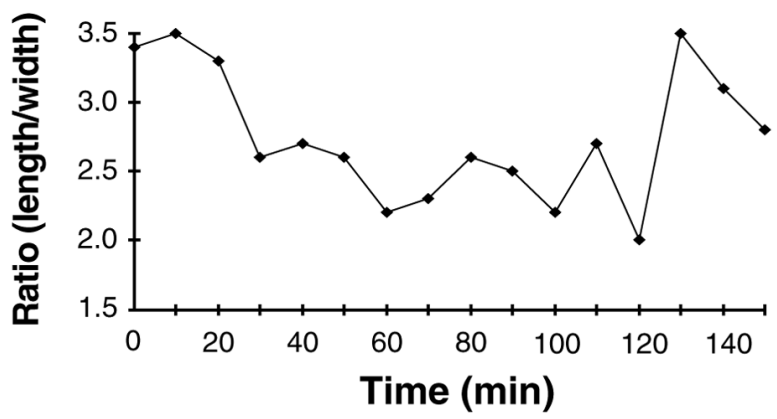

E

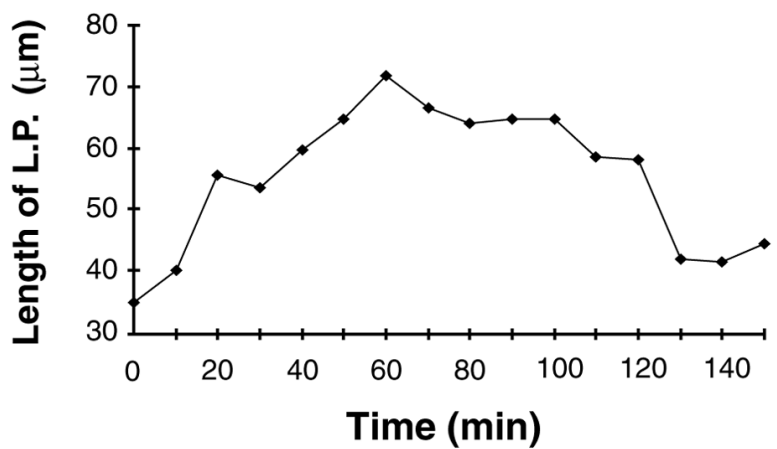

Figure 2. Tangential migration of a granule cell in the middle level of the EGL. A, During the observation period, the granule cell soma (white asterisks) gradually moved toward the left side of the cerebellar hemisphere at a rate of $18.8 \mu \mathrm{m} / \mathrm{hr}$. The distal portion of the leading process had large motile lamellipodia (small white arrowheads). Time interval (in minutes) is indicated on the top right of each photograph. Scale bar, $10 \mu \mathrm{m}$. The total distance traversed by the granule cell soma $(B)$, the direction and distance traveled by the soma during each $10 \mathrm{~min}$ of the testing period $(C)$, the length/width ratio of the soma $(D)$, and the leading process length $(E)$ were plotted as a function of elapsed time. In $C$, positive values represent forward cell movement, and negative values represent backward cell movement. 
A
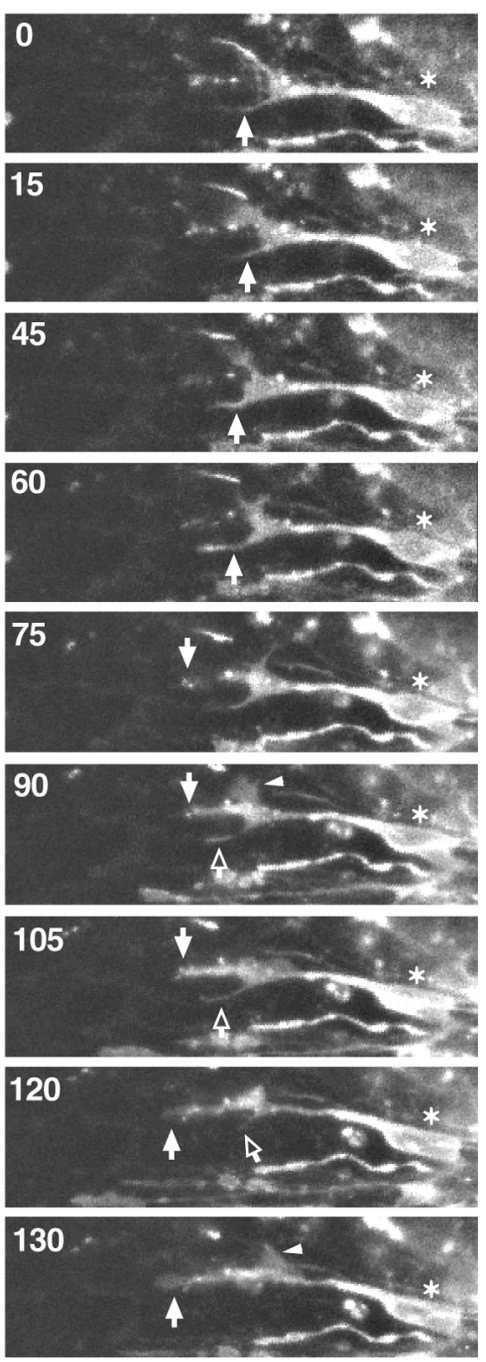
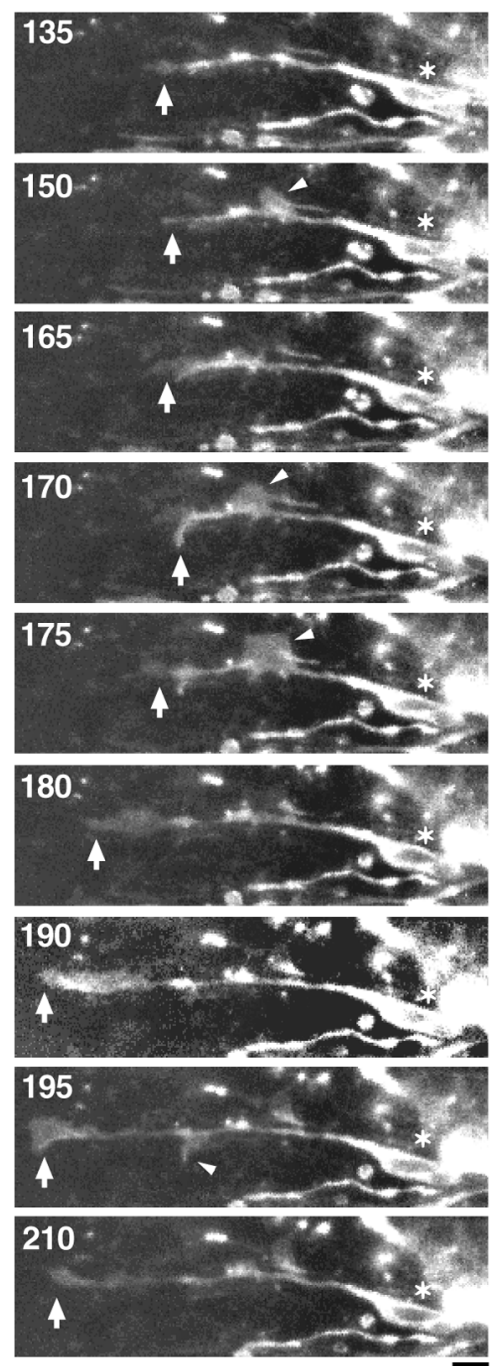

B

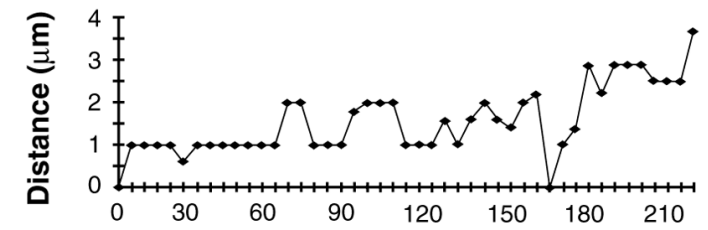

C

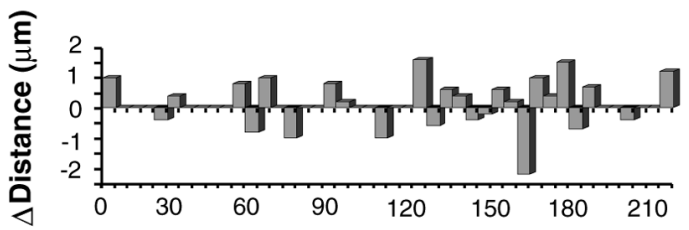

D
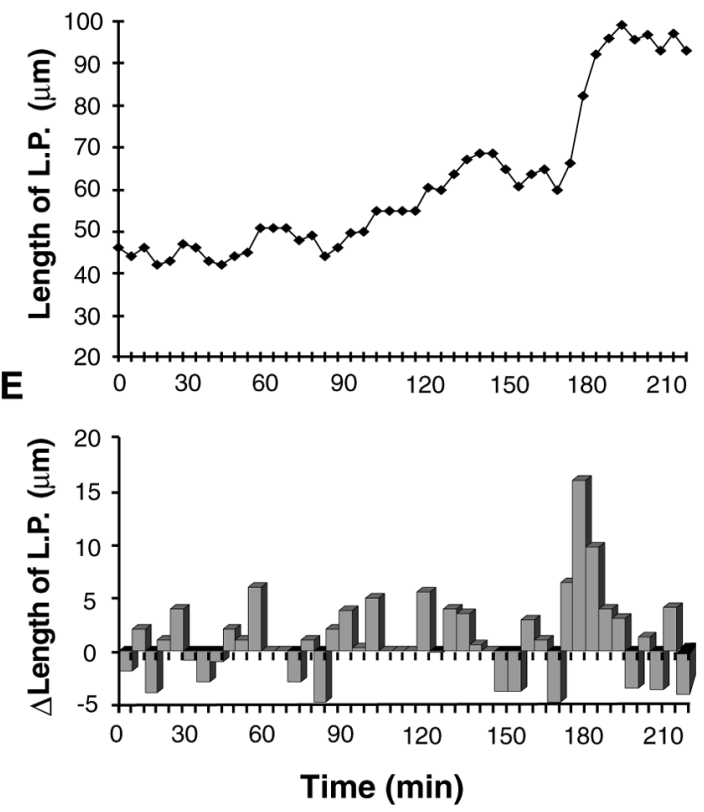

Figure 3. Postmitotic granule cell extending its voluminous leading process without active cell movement. $A$, In the middle level of the EGL, the cell body of a granule cell (white asterisks) remained stationary for $>3 \mathrm{hr}$, while its voluminous leading process (white arrows) extended continuously. Time interval (in minutes) is indicated on the top left of each photograph. Scale bar, $10 \mu \mathrm{m}$. The total distance traversed by the granule cell soma $(B)$, the direction and distance traveled by the soma during each $5 \mathrm{~min}$ of the testing period $(C)$, the leading process length $(D)$, and changes in the leading process length during each $5 \mathrm{~min}$ of the testing period $(E)$ were plotted as a function of elapsed time.

active cell migration. This sampling procedure favored slices in which cells displayed visible and robust movement and alteration of morphology shortly after sectioning. Images of the postmitotic granule cells in a single focal plane or up to 40 different focal planes along the $z$-axis were collected with laser scans every 5-10 min for up to $10 \mathrm{hr}$ and recorded on an external drive (Jaz 2GB; Iomega, Roy, UT). At the beginning and end of each recording session for each preparation, frame images were recorded with $40 \times$ (electronical zoom factor of 1 ) or $20 \times$ (electronical zoom factor of 1) magnification to determine the orientation of the slice preparations, the borders between the EGL and the ML, and the position of granule cells within the EGL by optical sectioning of several different focal planes along the $z$-axis. Statistical significance between experimental groups was tested by Student's $t$ test.

The length/width ratio of the soma and leading process length of each migrating granule cell were determined manually with a mouse-driven imaging software package. The leading process length was defined as the linear distance between its tip and its base. The distance traveled by a migrating granule cell was defined as the absolute value of the changes in its position during the entire time-lapse session.

5-Bromo-2'-deoxy-uridine labeling and immunohistochemistry. To determine the time course of granule cell migration, postnatal 10-d-old mice were injected intraperitoneally with 5-bromo-2'-deoxy-uridine (BrdU) (50 $\mathrm{mg} / \mathrm{kg}$ body weight), which was incorporated into the DNA of dividing cells during the S-phase of the cell cycle, and were killed $2 \mathrm{hr}$, $1 \mathrm{~d}$, and $2 \mathrm{~d}$ later (Kuhn et al., 1996). After an anesthetic overdose, all animals were transcardially perfused with $4 \%$ paraformaldehyde. Brains were removed, post-fixed in $4 \%$ paraformaldehyde for $24 \mathrm{hr}$, and stored in a $30 \%$ sucrose solution. Brains were embedded in Tissue-Tek (Sakura Finetechnical Corp., Torrance, CA) and sectioned horizontally into $30-\mu \mathrm{m}$-thick slices on a cryostat. For detection of BrdU-labeled nuclei in tissue sections, the following DNA denaturation steps proceeded the incubation with anti-BrdU antibody: $2 \mathrm{hr}$ incubation in 50\% formamide $-2 \times \operatorname{SSC}(0.3 \mathrm{M} \mathrm{NaCl}$ and $0.03 \mathrm{M}$ sodium citrate $)$ at $65^{\circ} \mathrm{C}, 5 \mathrm{~min}$ rinse in $2 \times \mathrm{SSC}, 30 \mathrm{~min}$ incubation in $2 \mathrm{~N} \mathrm{HCl}$ at $37^{\circ} \mathrm{C}$, and $10 \mathrm{~min}$ rinse in $0.1 \mathrm{M}$ boric acid, $\mathrm{pH}$ 8.5. After completion of DNA denaturation, cells that had incorporated BrdU into DNA were detected by an anti-BrdU monoclonal antibody (BrdU Labeling and Detection Kit I; Boehringer Mannheim, Indianapolis, IN) and fluorescein-conjugated secondary antibody. Fluorescent signals were detected and processed using a confocal microscope.

\section{RESULTS}

Itinerary of postmitotic granule cells within the EGL

To determine the time course of translocation of granule cells after their final mitosis within the EGL, we injected BrdU into 
A

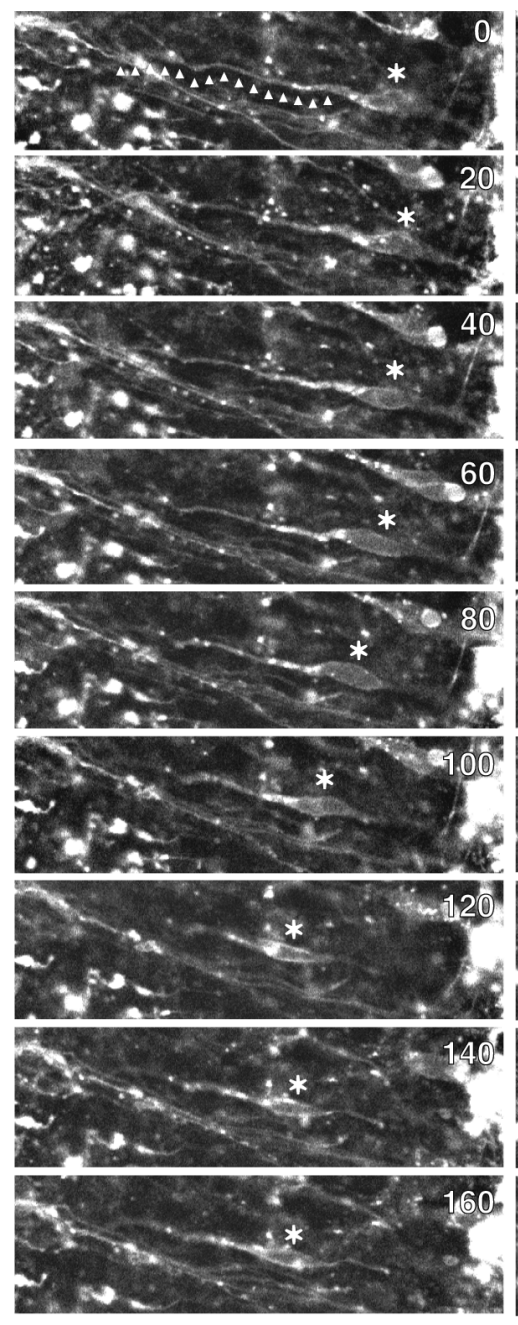

B

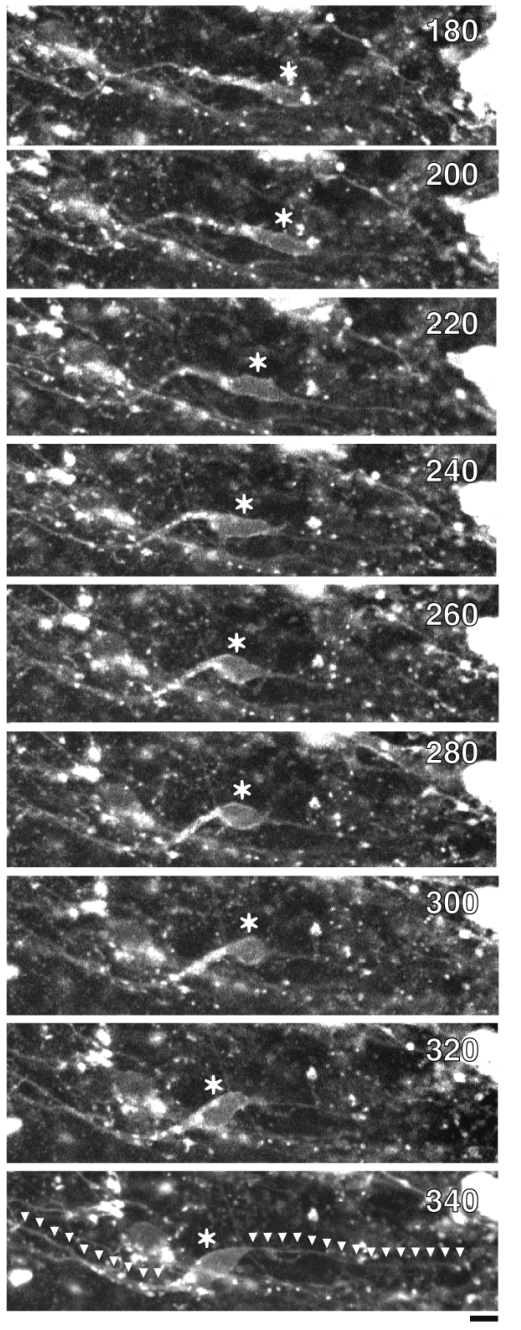

D
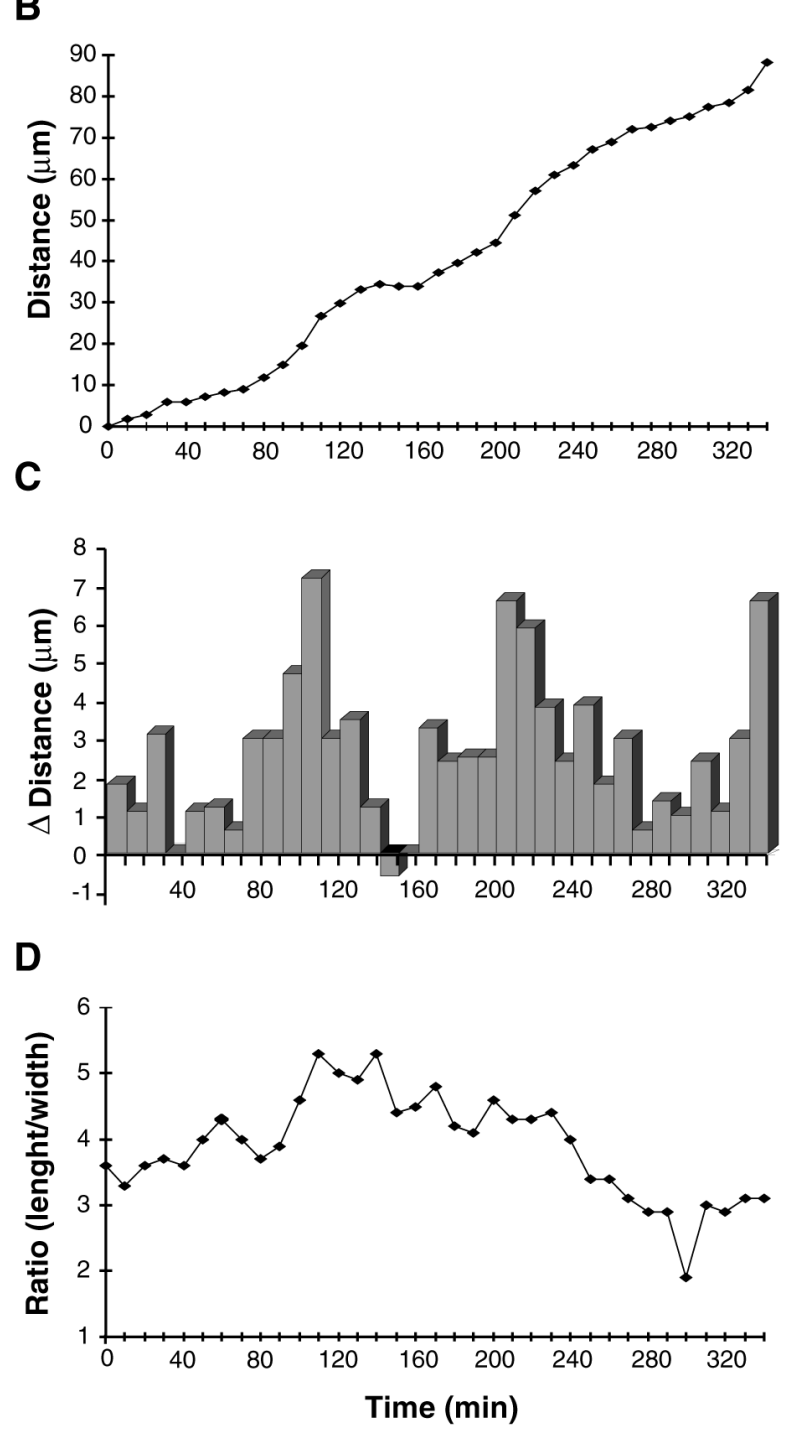

Figure 4. Tangential movement of a granule cell in the bottom level of the EGL. $A$, During the observation period, the spindle-shaped soma of the granule cell having two long horizontal processes (white arrowheads) migrated toward the left side of the hemisphere. Time interval (in minutes) is indicated on the top right of each photograph. Scale bar, $10 \mu \mathrm{m}$. The total distance traversed by the granule cell soma $(B)$, the direction and distance traveled by the soma during each $10 \mathrm{~min}$ of the testing period $(C)$, and the length/width ratio of the soma $(D)$ were plotted as a function of elapsed time.

postnatal 10-d-old mice and killed them 2, 24, and $48 \mathrm{hr}$ later. Two hours after injection, BrdU-labeled cells were localized at the outermost two rows of the EGL, showing directly that granule cell precursors proliferate within the top level of the EGL, whereas the middle and bottom levels of the EGL contain unlabeled postmitotic granule cells (Fig. 1 $A a$ ). Within the next $24 \mathrm{hr}$, the BrdU-labeled cells spread across the entire EGL, and some (Fig. 1Ab, white arrowheads) begin their descent to the ML. Two days after injection, $\sim 50 \%$ of BrdU-labeled cells have left the EGL and translocated their soma into the ML, Purkinje cell layer (PCL), or IGL (Fig. 1Ac). Previous studies indicated that the postsynthetic $\left(\mathrm{G}_{2}\right)$ phase and the mitotic (M) phase of the cycle of the granule cell precursor in 10-d-old mouse cerebellum last 2 and $0.5 \mathrm{hr}$, respectively (Fujita, 1967). Together, these results demonstrate that, after final cell division, postmitotic granule cells remain in the EGL between 20 and $48 \mathrm{hr}$ before the initiation of their radial migration across the ML.

We next examined the morphological characteristics of granule cells located at different levels of the EGL. Transverse sections were obtained from postnatal 10-d-old mouse cerebellum, and the cells were visualized $2 \mathrm{hr}$ after staining with DiI (Fig. 1). The cell located near the top level of the EGL (Fig. 1B,a) has a round shape, lacking the long processes as described in previous Golgi (Ramon y Cajal, 1911) and electron microscopic (Rakic, 1971, 1972, 1985) studies. In the middle and bottom levels of the EGL, the cells assume a spindle shape, oriented parallel to the longitudinal axis of the folium with two horizontal processes emanating from the opposite poles of their soma (Fig. $1 B, b, c)$. The two processes of the cell in the middle level of the EGL are always different in size; one process is thicker and $\sim 50 \mu \mathrm{m}$ long, similar to a leading process with a large filopodium at its tip (white arrow), whereas the other process is thin and short $(25 \mu \mathrm{m})$, reminiscent of an axon. In contrast, both horizontal processes of the cell in the bottom level of the EGL are usually longer than $100 \mu \mathrm{m}$ (white arrowheads) and uniform in diameter. At the border between the EGL and the ML, the granule cell (Fig. $1 B, d$ ) again acquires a rounded shape of its soma as it emanates the third, vertically oriented process as it penetrates the ML (open arrow). These results confirm that postmitotic granule cells undergo dynamic changes in their morphology while remaining in the EGL (Rakic, 1971, 1985). 

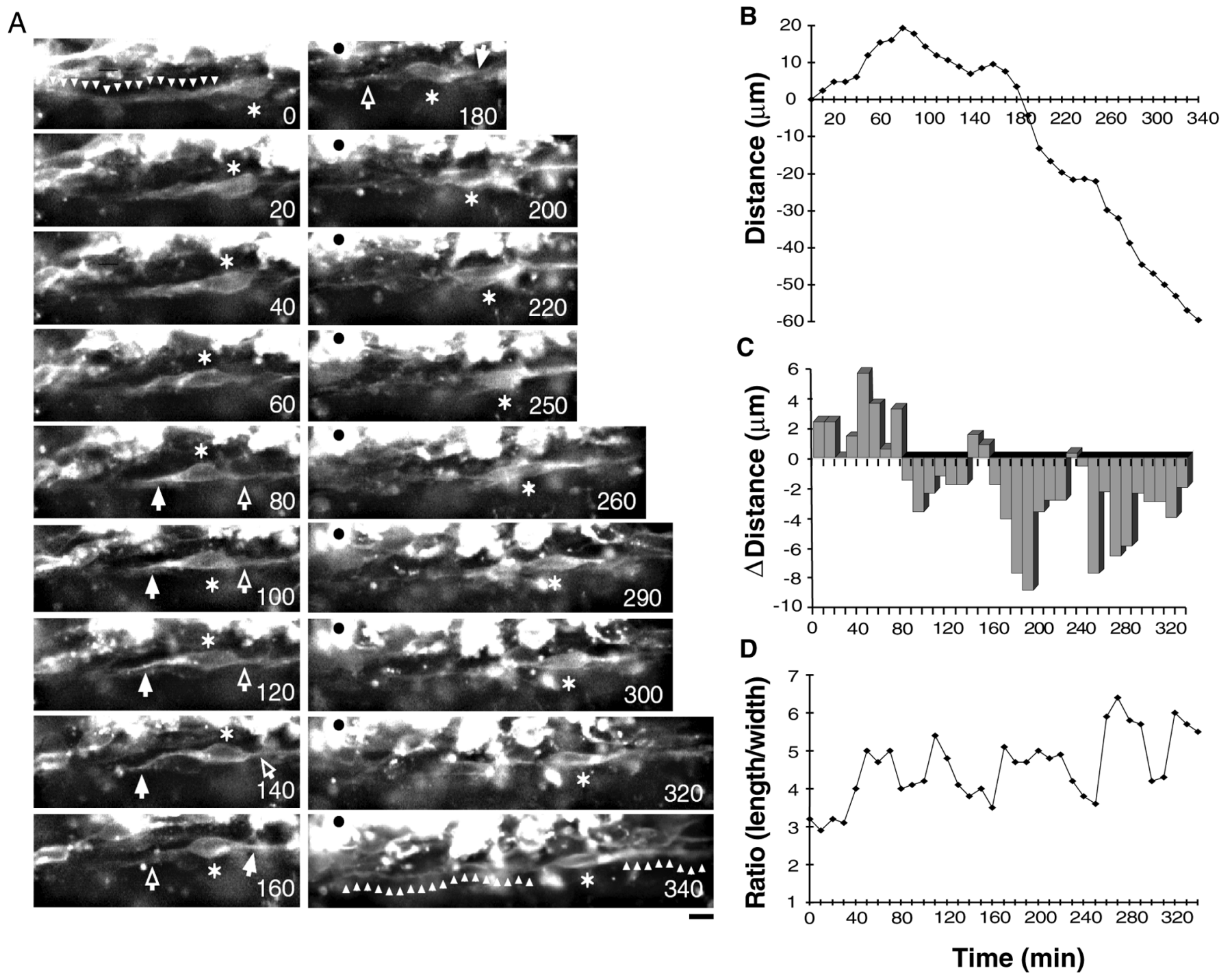

Figure 5. A reverse in the direction of tangential movement of a granule cell in the bottom level of the EGL. A, The horizontally oriented cell body (white asterisks) of the granule cell initially moved toward the left hemisphere at a rate of $14.6 \mu \mathrm{m} / \mathrm{hr}$, and 80 min later, changed its direction of movement and started to migrate toward the right hemisphere at a rate of $17.9 \mu \mathrm{m} / \mathrm{hr}$. Black circles represent a reference point. Time interval (in minutes) is indicated on the bottom right of each photograph. Scale bar, $10 \mu \mathrm{m}$. The total distance traversed by the granule cell soma $(B)$, the direction and distance traveled by the soma during each $10 \mathrm{~min}$ of the testing period $(C)$, and the length/width ratio of the soma $(D)$ were plotted as a function of elapsed time. In $B$ and $C$, positive values represent cell movement toward the left hemisphere, and negative values represent cell movement toward the right hemisphere.

\section{Tangential cell migration in the middle level of the EGL}

We used confocal microscopy to examine dynamic changes in the shape and behavior of the postmitotic granule cells at different levels of the EGL in real time. For example, the cell illustrated in Figure $2 A$ was visualized $2 \mathrm{hr}$ after staining, and its movement was recorded in optical sections at 10 min intervals for up to 150 min. At the beginning of the recording, it had a horizontally oriented, spindle-shaped cell body, a thin trailing process, and a voluminous leading process as described in Golgi-impregnated sections (Ramon y Cajal, 1911; Rakic, 1971) and electron microscopic preparations (Rakic, 1985). The distal portion of the leading process had large motile lamellipodia (white small arrowheads). During the observation period, the granule cell soma (white asterisks) with an elongated bipolar shape (length vs width ratio of 2.0-3.5) (Fig. $2 B, D$ ) was initially located $\sim 17 \mu \mathrm{m}$ away from the pial surface, near the midline of the pyramis, and was gradually displaced toward the left side of the cerebellar hemi- sphere at a rate of $18.8 \mu \mathrm{m} / \mathrm{hr}$. Although the distance traversed by the granule cell gradually increased, the cell body did not move linearly (Fig. 2C). Rather, the migration speed of the cell body fluctuated between phases of rapid advancement to a complete curtailment of movement, similar to the saltatory movement of the glial cell-associated migration observed in the ML (Komuro and Rakic, 1995, 1998a).

At the beginning of the observation, a voluminous leading process extended laterally, and its length increased from 35 to 71 $\mu \mathrm{m}$ (Fig. 2E). However, $60 \mathrm{~min}$ later, the tip of the leading process (white arrows) stopped growing. The shortening of the leading process from 71 to $40 \mu \mathrm{m}$ (Fig. $2 E$ ) is attributable to the translocation of the granule cell soma within the leading process rather than its active retraction. The present results demonstrate that, in the middle level of the EGL, the postmitotic granule cell, which has a short leading process and a thin trailing process, migrates laterally (parallel to the folial folds) with a speed similar 
A
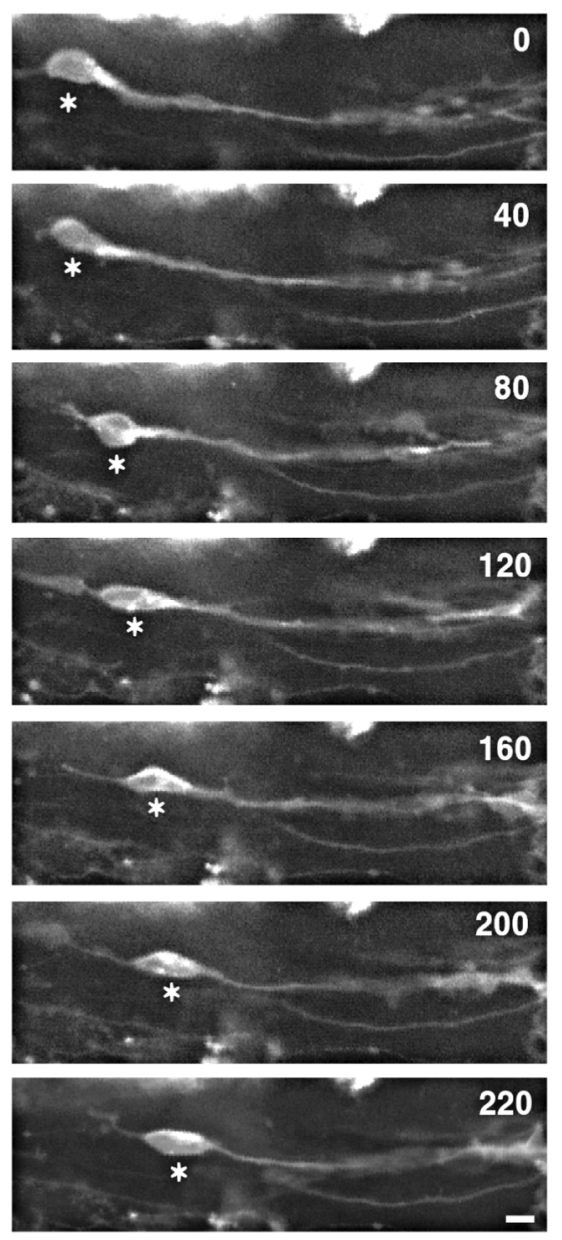

B

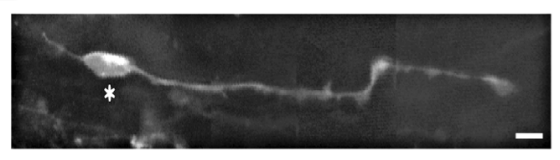

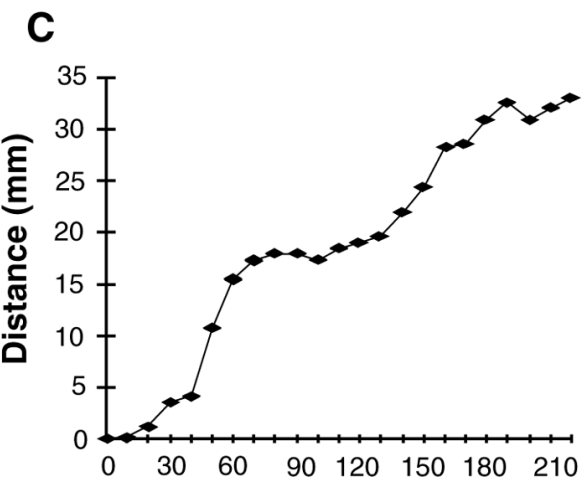

D

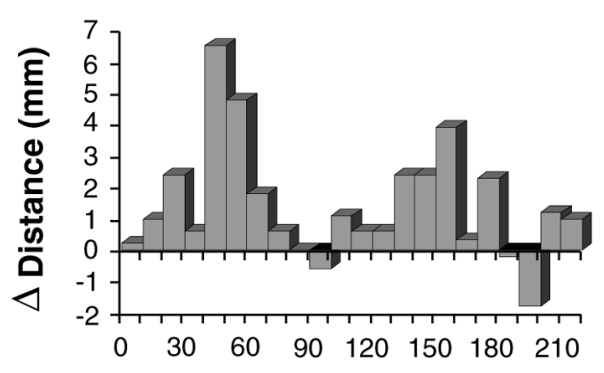

E

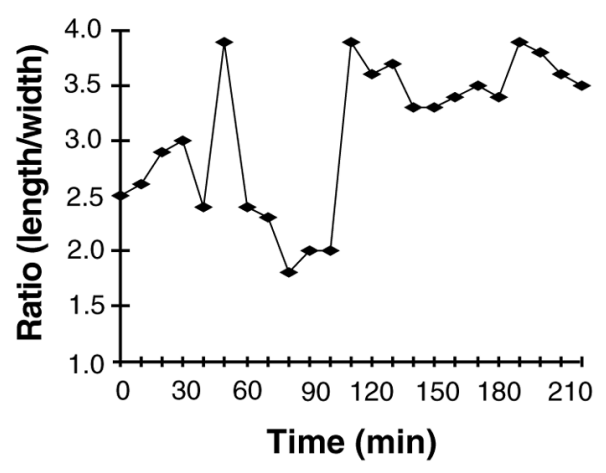

Figure 6. Slowdown of tangential movement of a granule cell with longer horizontal processes. $A$, During the period of observation, the cell with longer horizontal processes moved toward the right side of the hemisphere at a reduced rate of $9.1 \mu \mathrm{m} / \mathrm{hr}$. Interestingly, the cell did not protrude filopodia and lamellipodia from its cell body and horizontal processes. Time interval (in minutes) is indicated on the top right of each photograph. Scale bars, $10 \mu \mathrm{m}$. $B$, A photograph representing the long horizontal process of tangentially migrating granule cell shown in $A$. The total distance traversed by the granule cell soma $(C)$, the direction and distance traveled by the soma during each $10 \mathrm{~min}$ of the testing period $(D)$, and the length/width ratio of the soma $(E)$ were plotted as a function of elapsed time. to that observed in the ML for cell migrating radially (Komuro and Rakic, 1995, 1998a). We also found that, in the middle level of the EGL, the spindle-shaped cell body of a granule cell (white asterisks) initially located $\sim 18 \mu \mathrm{m}$ away from the pial surface near the midline of the pyramis remained stationary for $>3 \mathrm{hr}$, while its voluminous leading process (white arrows) continued to grow (Figs. 3A-C). During a $220 \mathrm{~min}$ observation period, the length of the leading process doubled (from 46 to $95 \mu \mathrm{m}$ ) (Fig. 3D,E). The leading process often developed actively motile filopodia (open arrows) near the tip and lamellipodia at the center (white small arrowheads), although their soma do not migrate during extension of the horizontal processes.

Among 124 granule cells examined in the middle level of the EGL in transverse or sagittal slices, 92 cells (83\% of total cells) migrated in the transverse plane (parallel to the folium) at a speed of $>10 \mu \mathrm{m} / \mathrm{hr}, 17$ cells (9\%) migrated at the speed between 5 and $10 \mu \mathrm{m} / \mathrm{hr}$, and 15 cells $(7 \%)$ moved at the rate $<5 \mu \mathrm{m} / \mathrm{hr}$ or remained stationary. Moreover, we did not find any postmitotic granule cells showing the anteroposterior movement (perpendicular to the folium) in the middle level of the EGL. Thus, the majority of the postmitotic granule cells located in the middle level of the EGL actively migrate in the transverse plane.

\section{Direction and rate of cell movement at the bottom of the EGL}

Next we examined granule cell behavior and change in their morphology at the bottom of the EGL. A typical example of a spindle-shaped granule cell located in the bottom level of the EGL (29 $\mu \mathrm{m}$ away from the pial surface) with two long (over 100 $\mu \mathrm{m})$ horizontal processes oriented parallel to the longitudinal axis of folia is provided in Figure $4 A$. During the observation period, its cell body (white asterisks) exhibited saltatory movement and migrated toward the lateral side of the hemisphere at the rate of $15.7 \mu \mathrm{m} / \mathrm{hr}$ (Figs. $4 B, C$ ), which is comparable with that observed in the ML and IGL (Komuro and Rakic, 1995, 1998a). The cell changed its shape during its movement, possibly as a result of squeezing past various obstructions in its environment (Fig. 4D). Interestingly, $260 \mathrm{~min}$ after the beginning of the recording, the horizontally extended leading process bent slightly toward the ML. However, after 340 min of recording, the tip of the leading process again changed the direction of extension toward the middle of the EGL (Fig. 4A, arrowheads). Although the tips of horizontally extending leading processes often exhibit upward and downward movement within the bottom of the EGL, 
A
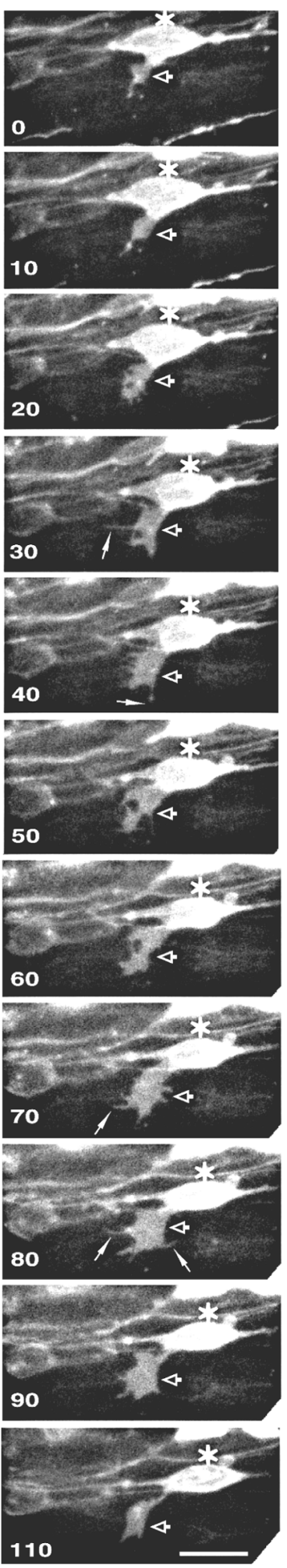

B

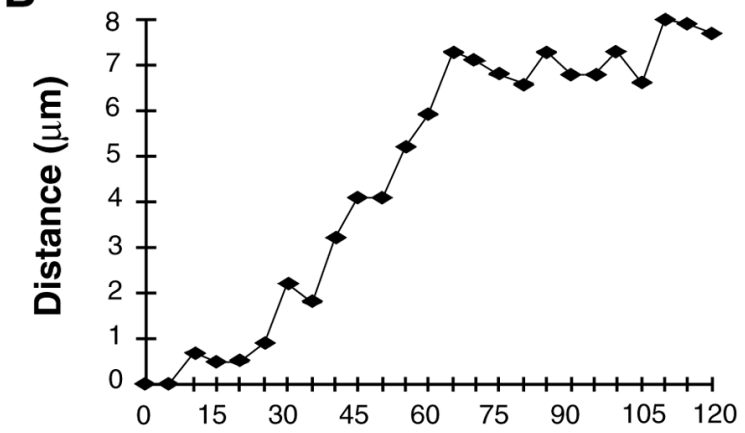

C
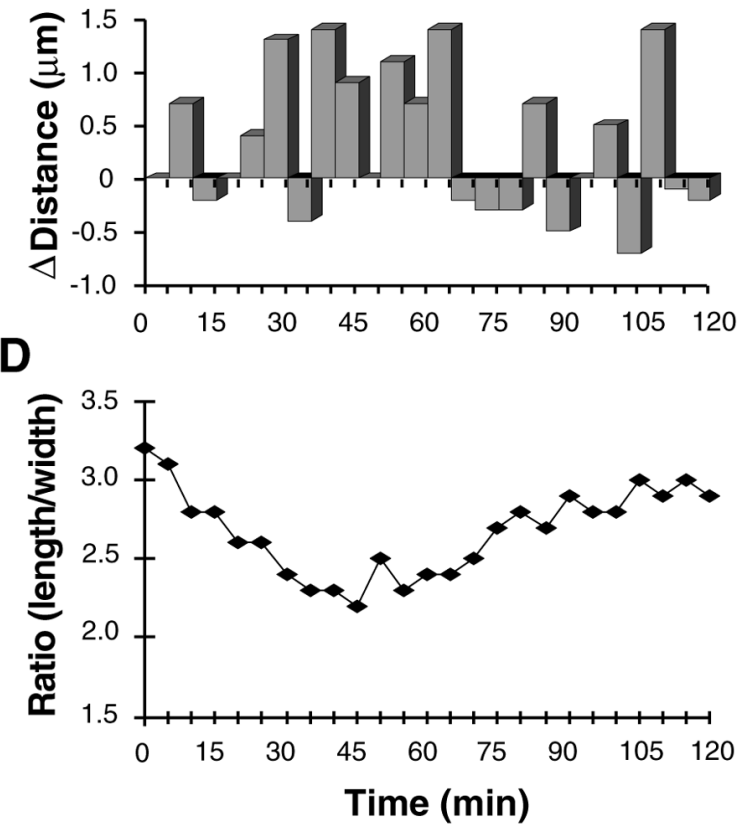

Figure 7. Slowly migrating granule cell with descending processes near the EGL-ML border. $A$, The highly motile processes having lamellipodia-like structure (open arrows) and filopodia (white arrows), extended from the cell body. During the process extension, the horizontally oriented cell body (asterisks) exhibited the tangential movement toward the right hemisphere of the cerebellum at a significantly reduced rate of $3.8 \mu \mathrm{m} / \mathrm{hr}$. Time interval (in minutes) is indicated on the bottom left of each photograph. Scale bar, $10 \mu \mathrm{m}$. The total distance traversed by the granule cell soma $(B)$, the direction and distance traveled by the soma during each $5 \mathrm{~min}$ of the testing period $(C)$, and the length/width ratio of the soma $(D)$ were plotted as a function of elapsed time.

the leading processes did not penetrate into the ML and did not transform into vertical processes. These results demonstrate that postmitotic granule cells located in the bottom level of the EGL do not stop their movement but continue to migrate in the mediolateral direction.

A small number of cells reverse the direction of cell body movement during the tangential migration at the bottom level of the EGL. For example, we found that the horizontally oriented granule cell body (white asterisks) located $\sim 30 \mu \mathrm{m}$ away from the pial surface initially moved toward the left aspect of the hemisphere (Fig. 5A). However, $80 \mathrm{~min}$ after the beginning of the recording, the granule cell changed the direction of cell movement and started to migrate toward the right hemisphere (Fig. $5 B, C)$. It is likely that, during the transition period, while reversing the direction of cell movement, the granule cell altered its polarity. For example, during the first $140 \mathrm{~min}$ of recording, one 


\section{A}
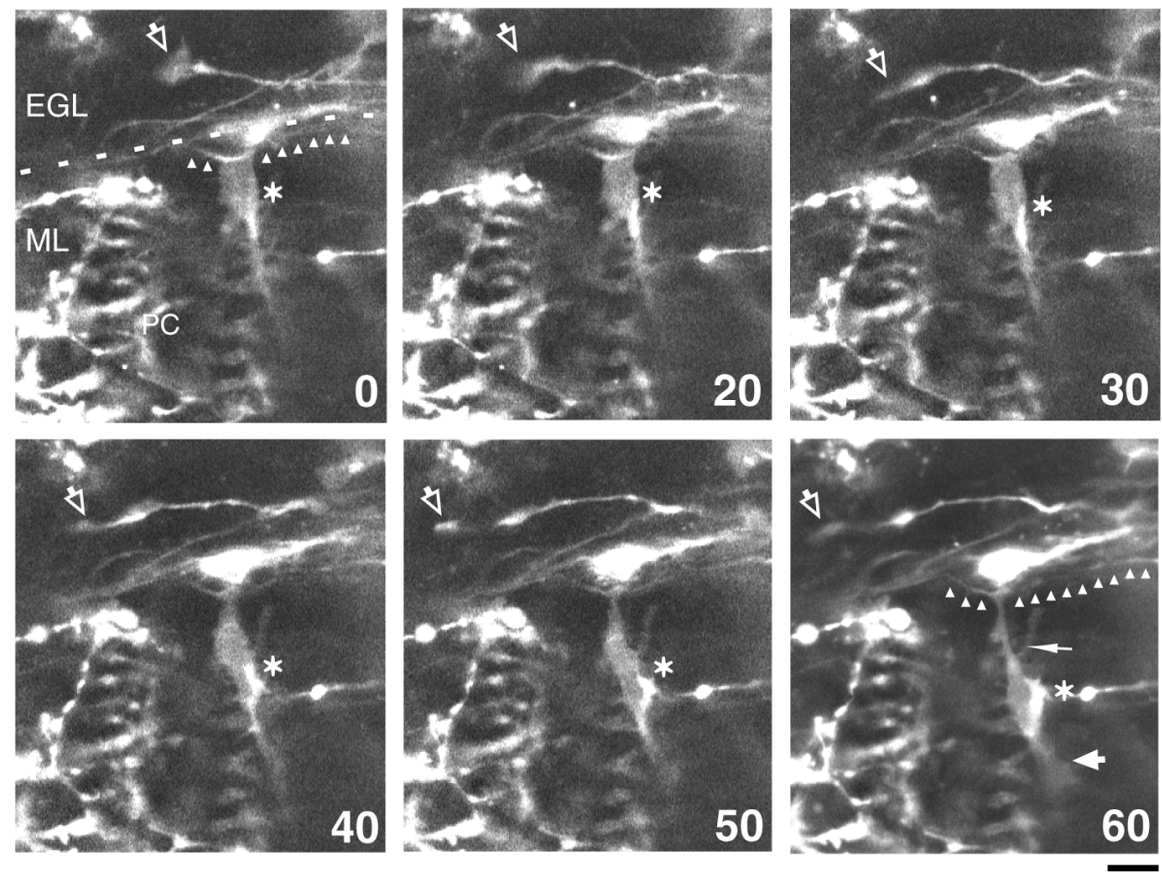

B

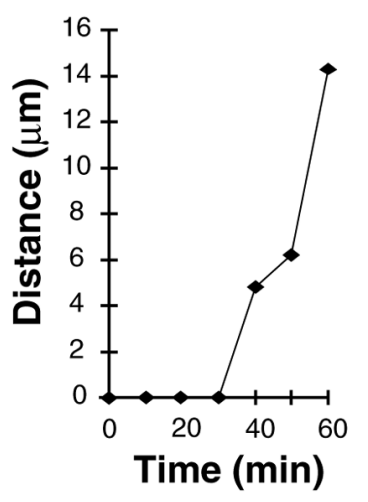

C

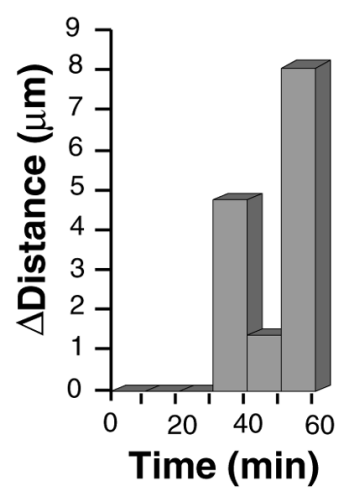

D

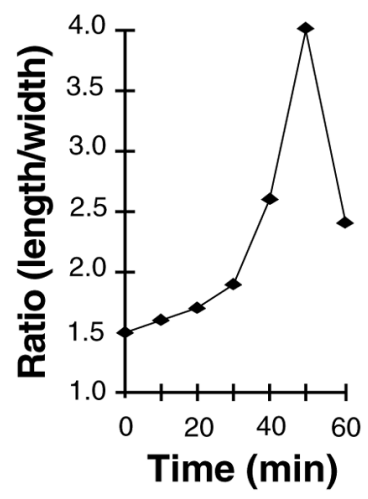

Figure 8. Initiation of vertical migration and formation of a T-shaped axon. $A$, At the beginning, a granule cell (asterisks) located near the EGL-ML border (dotted line), had vertically oriented soma with two horizontal and one vertical process. The cell remained stationary for the first $30 \mathrm{~min}$ before its soma quickly moved radially toward the bottom of the ML. As a result, the granule cell developed a trailing process (small arrow) and a T-shaped axon. Time interval (in minutes) is indicated on the bottom right of each photograph. Open arrows represent rapid extension of the horizontal process of other granule cells. Scale bar, $10 \mu \mathrm{m}$. The total distance traversed by the granule cell soma $(B)$, the direction and distance traveled by the soma during each 10 min of the testing period $(C)$, and the length/width ratio of the soma $(D)$ were plotted as a function of elapsed time.

horizontal process (white arrows) extending from the left side of the cell body was thicker, resembling the leading process, whereas the other horizontal process (open arrows) extending from the right side of the cell body was thinner, resembling the trailing process. However, $160 \mathrm{~min}$ after recording, the left side process became thinner, resembling the trailing process, whereas the right side process became thicker, resembling the leading process. The granule cell also changed the shape of its soma during the transition periods of cell polarity (Fig. $5 D$ ). Moreover, the cell slightly increased the rate of movement after changing the direction of migration from $14.6 \mu \mathrm{m} / \mathrm{hr}$ (toward the left side) to $17.9 \mu \mathrm{m} / \mathrm{hr}$ (toward the right side) (Fig. 5B). These results suggest that postmitotic granule cells located in the bottom level of the EGL may be able to alter the direction of cell movement, indicating the possibility that their cell polarity may not be rigid, but reversible, possibly in response to changes in the local cues.

Among the 120 granule cells examined in the bottom level of the EGL, the longest process extending from one side of the horizontally oriented granule cells was $190 \mu \mathrm{m}$ in the length. The two horizontal processes were usually not of even length. For example, Figure $6, A$ and $B$, illustrates that the granule cell located at the bottom level of the EGL ( $36 \mu \mathrm{m}$ away from the pial surface) had one long $(157 \mu \mathrm{m})$ and one short $(54 \mu \mathrm{m})$ horizontal process. During the period of our observation, the cell moved toward the right side of the hemisphere at a reduced rate of 9.1 $\mu \mathrm{m} / \mathrm{hr}$ while altering its cell body shape (Fig. $6 C-E$ ). During this period, the cell did not form filopodia and lamellipodia, except for the single small extension at the tip of the process. These results suggest that, at the bottom level of the EGL, granule cells with the longer horizontal processes move at a reduced rate.

\section{Cessation of tangential migration at the interface of the EGL and ML}

How do granule cells change the direction of migration from tangential to radial? How do granule cells initiate their radial migration through the ML? Are there specific signs indicating the time and place for the initiation of radial migration? These questions are critical for understanding the cellular and molecular mechanisms underlying the transition between the two modes of granule cell migration. To address these issues, we examined the changes in morphology and behavior of horizontally oriented granule cells situated near the border between the EGL-ML. Figure 7 illustrates a granule cell located near the border between the EGL and ML that extrude large third processes from the 
A
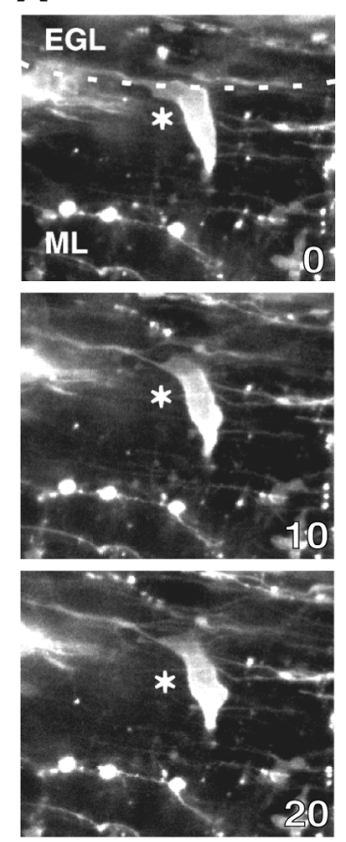

Figure 9. Extrusion of one side of the parallel fibers during initiation of vertical migration of a granule cell. $A$, During the first $30 \mathrm{~min}$, the granule cell (asterisks) located near the EGL-ML border (dotted line), had a single horizontal process extending toward the left side. Forty minutes later, the cell developed a small horizontal process (open arrow) at the rear part of its soma toward the right side. As a result of downward movement of the soma, the cell developed a T-shaped axon branch. Time interval (in minutes) is indicated on the bottom right of each photograph. Scale bar, $10 \mu \mathrm{m}$. The total distance traversed by the granule cell soma $(B)$, the direction and distance traveled by the soma during each 5 min of the testing period $(C)$, and the length/width ratio of the soma $(D)$ were plotted as a function of elapsed time.
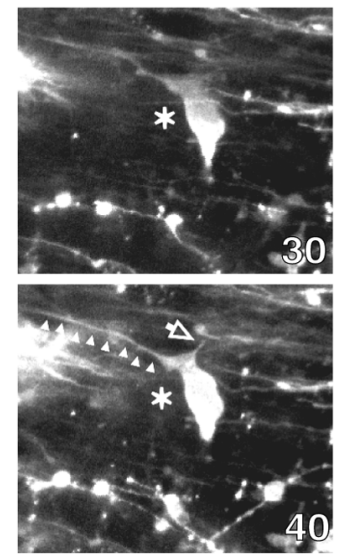

center of its soma. During the period of recording, this highly motile process with lamellipodia (open arrows) and filopodia (white arrows) at the tip extended from the spindle-shaped cell body into the ML (Fig. 7A). The length versus width ratio of the cell body during this period was consistently low, with a range of 3.2-2.1 (Fig. 7D). During extension of the vertical process, a horizontally oriented cell body (asterisks) exhibited the tangential movement toward the right hemisphere at a significantly reduced speed of $3.8 \mu \mathrm{m} / \mathrm{hr}$ (Fig. $7 B, C$ ). These results suggest that significant reduction in tangential cell body movement occurs during extrusion of vertical processes into the ML as a sign for ending tangential migration at the interface of the EGL and ML. Furthermore, the newly extended vertical processes may actively search for potential guidance cues responsible for changing the direction of cell movement from tangential to radial.

\section{Initiation of radial migration}

How and at which site do granule cells alter their mode and direction of migration from glia-independent, tangential movement in the EGL to the Bergmann glia-dependent radial movement in the ML? How do granule cells generate their axon, known as parallel fibers, during the transition phase from one form of migration to another? To address these questions, we
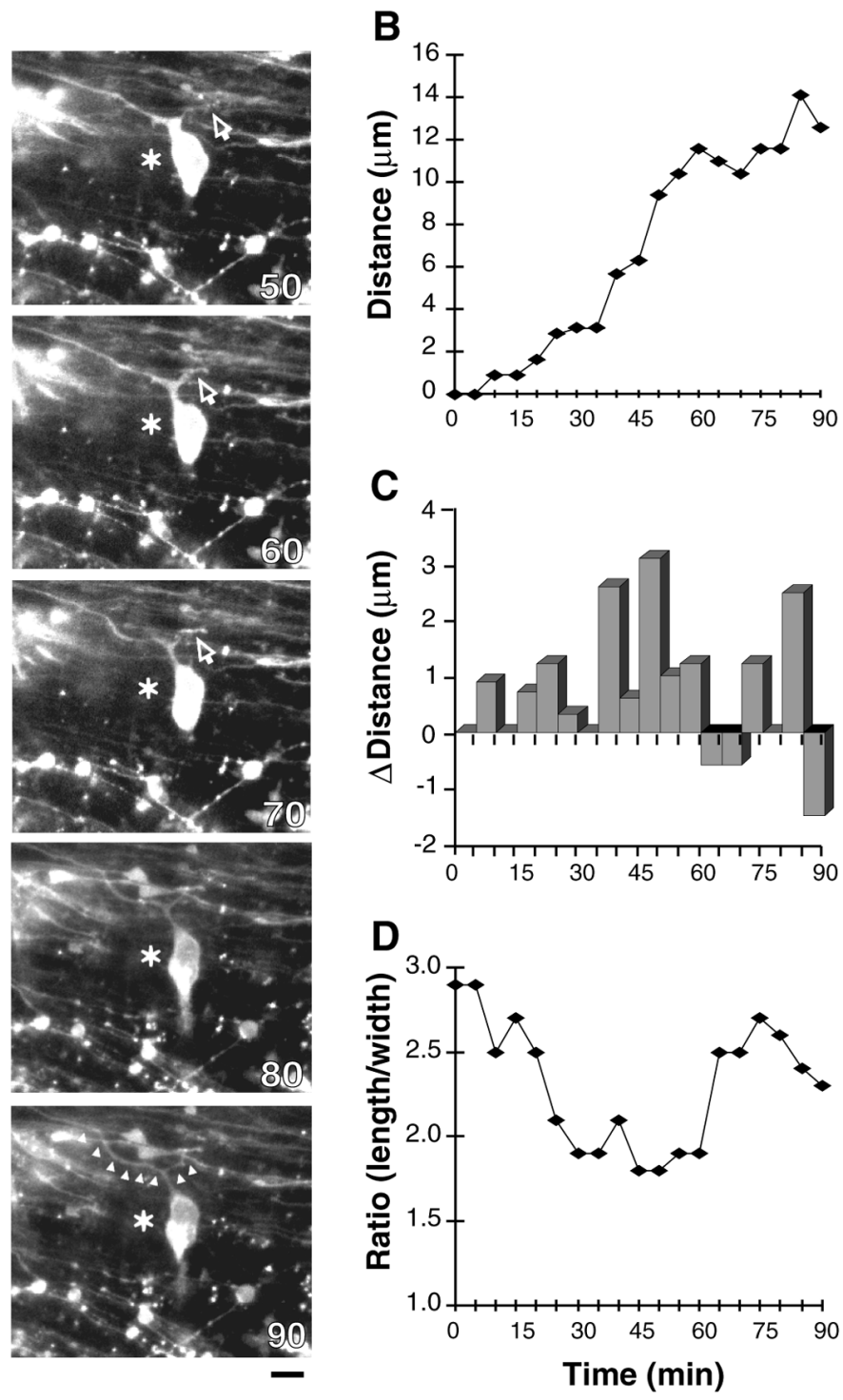

have examined the onset of radial migration of granule cells at the interface between the EGL and the ML. At the beginning of recording, a granule cell (asterisks) located at the interface between the EGL and ML (dotted line) retained two elongated horizontal processes, whereas its nucleus and surrounding cytoplasm started to enter into the short vertical process descending into the ML (Fig. $8 A$ ). It took $\sim 30$ min for the completion of the translocation of its nucleus and surrounding cytoplasm from the horizontally extended process to the vertical process. After the completion of change in nucleus orientation, the soma quickly moved toward the bottom of the ML (Fig. 8B,C). During the translocation, the shape of its soma transformed from a sphere (a length vs width ratio of $1.5-1.8)$ to a vertically elongated spindle (a length vs width ratio of 2.5-4.0) (Fig. 8D). As a result of the translocation of the soma within the leading process, the granule cell develops a thin trailing process connected with two horizontal processes (immature parallel fiber) (Fig. 8A). These results demonstrate in real time that two horizontal processes emitted from each side of granule cell soma at the bottom level of the EGL transform into future parallel fibers, as deduced from the light and electron microscopic observations (Rakic, 1971).

Although the majority of parallel fibers develop from the two 
A
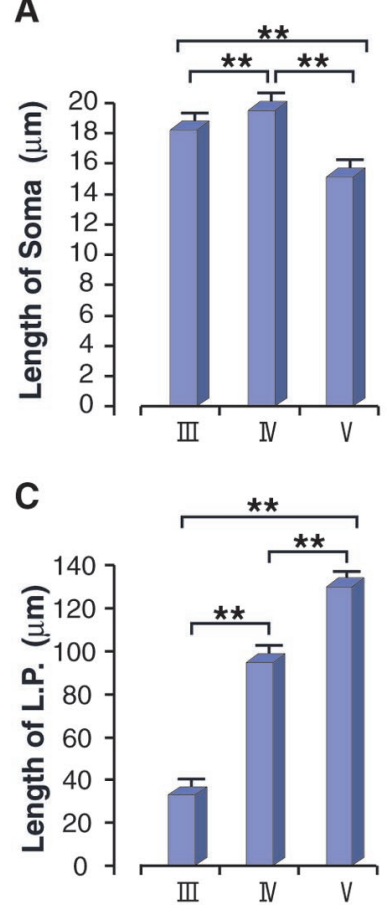

E

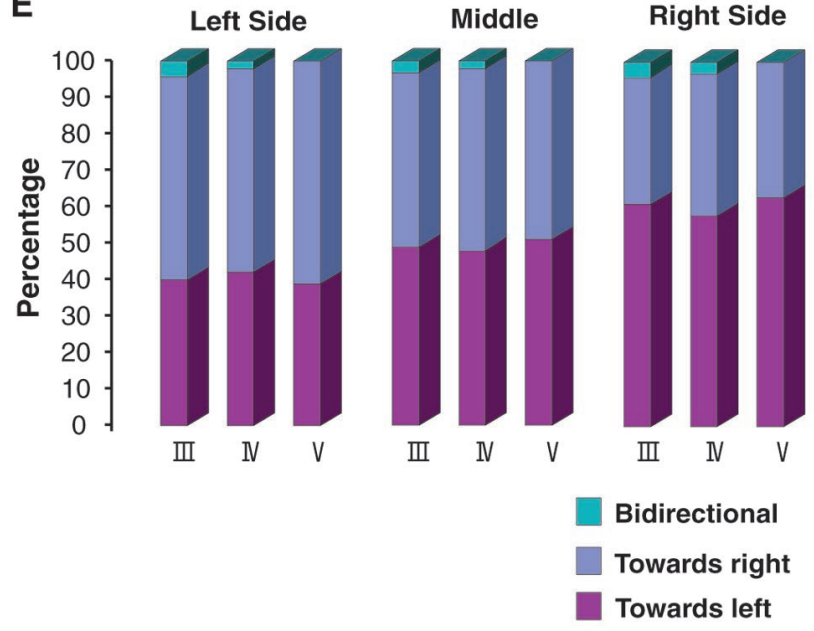

Figure 10. $A-E$, Histograms of soma length $(A)$, soma width $(B)$, leading process length $(C)$, movement $\operatorname{rate}(D)$, and movement direction $(E)$ of granule cells in the EGL. To categorize the morphology and behavior of the postmitotic granule cells within the EGL, we divided the width of the EGL of the P10 mouse into five levels: levels I, II (proliferating cell layer; within $12 \mu \mathrm{m}$ of the pial surface); level III (postmitotic cell layer; within $18 \mu \mathrm{m}$ of the pial surface); level IV (postmitotic cell layer; within $24 \mu \mathrm{m}$ of the pial surface); and level $V$ (postmitotic cell layer; over $24 \mu \mathrm{m}$ from the pial surface). Each column represents the average values obtained from 80 migrating granule cells in level III, 75 cells in level IV, and 64 cells in level V. ${ }^{*} p<0.05$ and ${ }^{* *} p<0.01$ indicate statistical significance.

pre-existing horizontal processes of a tangentially migrating granule cell, we observed here another mechanism for the formation of parallel fibers. Figure $9 A$ illustrates that, during the initiation of vertical migration near the EGL and ML border (dotted line), a vertically oriented granule cell may initiate a new process, which becomes one side of the parallel fibers. During the first $30 \mathrm{~min}$ of recording, the granule cell (asterisks) had a single horizontal process extending toward the left side of the cerebellum. After 40 min of recording, the cell developed a new small process (open arrow) at the rear part of the vertically elongated soma directed toward the right side (Fig. 9A). Thus, the T-shaped axon consisting of a trailing process and the two arms of the future parallel fiber is formed during the course of downward movement of the soma (Fig. 9B,C). Interestingly, during the process of the initiation of radial migration, the soma of the granule cell became transiently round (Fig. 9D) and withdrew its vertical process. However, $40 \mathrm{~min}$ after rounding, the soma assumed its spindle shape and re-extended its vertical process toward the ML (Fig. $9 A$ ). These results demonstrate that, in some cases, one side of a parallel fiber originates from a single horizontal process of laterally migrating granule cells in the EGL, whereas the other side develops later in a separate manner.

\section{Speed and direction of granule cell migration depend on their position in the EGL}

To further elucidate the behavior of postmitotic granule cells in the EGL, we examined the relationship between the vertical levels of granule cells within the EGL, their morphology (Fig. 10A-C), and the rate of their migration (Fig. 10D). In the postnatal 10 -d-old mouse cerebellum, the EGL in the pyramis is $\sim 30 \mu \mathrm{m}$ wide and consists of approximately five to six rows of tightly packed granule cells (proliferating cells at the top two rows, and postmitotic cells at the bottom three to four rows). To categorize the morphology and behavior of the postmitotic granule cells within the EGL, we divided the thickness of the EGL into five levels: the first (I) and second (II) levels (proliferating cell layer), within $12 \mu \mathrm{m}$ of the pial surface; the third (III) level (postmitotic cell layer), within $18 \mu \mathrm{m}$ of the pial surface; the fourth (IV) level (postmitotic cell layer), within $24 \mu \mathrm{m}$ of the pial surface; and the fifth (V) level (postmitotic cell layer), over $24 \mu \mathrm{m}$ from the pial surface. As presented quantitatively in the histograms (Fig. 10 $A-$ $D)$, the morphology and behavior of the postmitotic granule cells depends on their vertical position. For example, the rate of granule cell movement is the fastest $(14.8 \pm 1.2 \mu \mathrm{m} / \mathrm{hr})$ in the third (III) level when cells have a short, leading process-like fiber $(32.9 \pm 1.3 \mu \mathrm{m})$ and horizontally oriented spindle-shaped soma (a length vs wide ratio of 3.0). In the fourth (IV) level, the granule cells slow down their movement to $12.6 \pm 0.6 \mu \mathrm{m} / \mathrm{hr}$ while extending their soma (a length vs wide ratio of 3.4) and leadinglike process $(94.5 \pm 2.0 \mu \mathrm{m})$. Cell movement of granule cells is the slowest $(4.1 \pm 0.4 \mu \mathrm{m} / \mathrm{hr})$ in the fifth (V) level after their somata become round (a length vs wide ratio of 2.2) and the leading-like processes further extend horizontally $(130.0 \pm 7.3$ $\mu \mathrm{m})$. These data suggest that postmitotic granule cells alter their shape and rate of movement in different levels of the EGL.

The real-time observation of identified granule cells also revealed a difference in direction of tangential cell migration between the midline and lateral regions of the cerebellum (Fig. $11 E$ ). Among 105 granule cells examined at the midline region of the cerebellum, 50 cells $(48 \%)$ migrated toward the right side of the hemisphere, 53 cells $(50 \%)$ migrated toward the left side, and only three cells $(2 \%)$ reversed the direction of their cell movement either from right side to left side or from left side to right side. Among 92 granule cells examined in the left hemisphere, 53 cells $(58 \%)$ migrated toward the right side of the hemisphere (toward the midline regions), 37 cells $(40 \%)$ migrated toward the left side, and only two cells (2\%) reversed their direction of cell movement. Among 96 granule cells examined in the right hemisphere, 36 cells $(38 \%)$ migrated toward the right side of hemisphere, 59 cells $(61 \%)$ migrated toward the left side (toward the midline regions), and only two cells $(2 \%)$ reversed the direction 


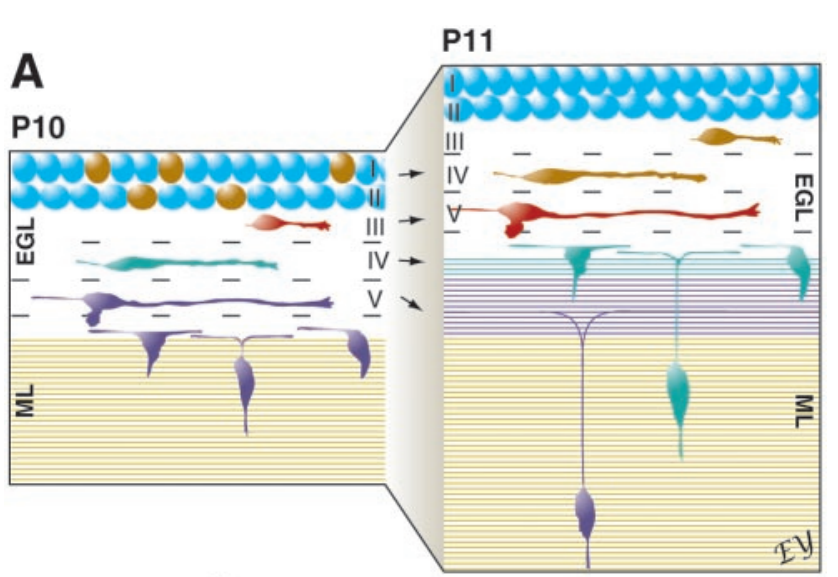

B
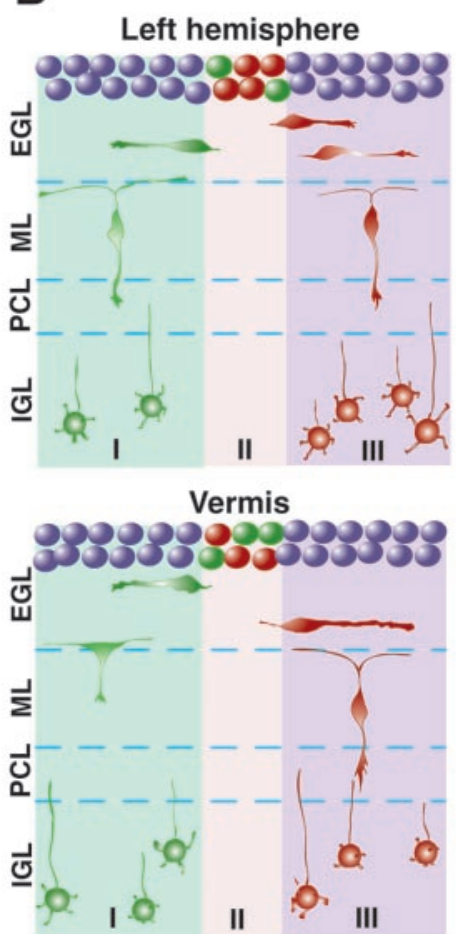

Right hemisphere

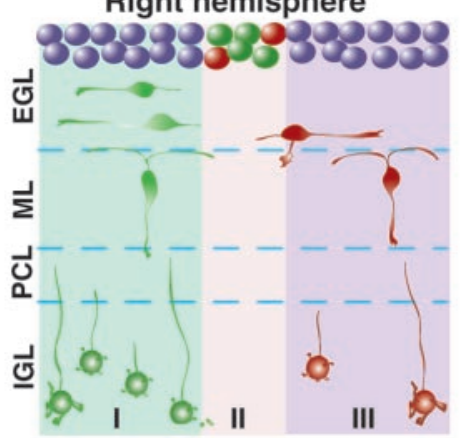

Figure 11. A, Shift of the geography of developing cerebellar cortex over time. At P10, the granule cell precursors proliferate within $\sim 19-21 \mathrm{hr}$ of the cell cycle within levels I and II of the EGL. Approximately $21 \mathrm{hr}$ after their final cell division, tangentially migrating granule cells change the orientation of their somata from horizontal to vertical and start to leave the EGL. As a result, their horizontal processes become parallel fibers, and the EGL-ML border moves up toward the pial surface (as seen at P11). Therefore, the granule cell, which initially migrates tangentially at level III of the EGL at P10, will be located at the level V after $24 \mathrm{hr}$ (at P11), without undergoing downward movement. $B$, Schematic drawing illustrating the hypothesis that granule cells may be specified to settle in a particular A-P compartment and have to travel tangentially over relatively long distances in the middle and the bottom of the EGL to reach a target compartment. of movement. These observations indicate that postmitotic granule cells located in the left or right side of the hemisphere tend to migrate toward the midline region, whereas the cells located in the midline region do not exhibit a preference in the movement direction between the left and right side. Furthermore, postmitotic granule cells located in the left or right side of the hemispheres may move in response to localized guidance cues. At present, the source or nature of either attractive or repulsive signals has not been identified.

\section{DISCUSSION}

The real-time observation in living slice preparations reveals that, after their last mitotic division, prospective granule cells remain in the EGL from 1 to $2 \mathrm{~d}$. During that period, the majority of postmitotic cells become oriented in the transverse plane, and their two horizontal processes transform into parallel fibers, as has been correctly inferred from the static Golgi preparations (Ramon y Cajal, 1911). In addition, we have observed substantial tangential migration during the period between the last cell division and the onset of their descent to the ML. The slice preparations expose vividly that cell shape, mode, and tempo of migration changes systematically according to their position within the EGL. In the middle of the EGL (Fig. 11 A, level III), which is situated below the proliferative cell layers (levels $I, I I$ ), the initially round, postmitotic cells elaborate two short but uneven horizontal processes, oriented parallel to the axis of the future folium and begin to migrate tangentially at the fastest rate. At the bottom level of the EGL (level $I V)$, granule cells acquire spindle-shaped somata and further extend two horizontal processes while moving at a slightly reduced rate. At the interface of the EGL and ML (level $V$ ), granule cells round their somata and reduce significantly their movement before forming the third vertical process that enters the radially developing ML. If we assume that postmitotic granule cells spend equal time at each level and that they do not reverse significantly their direction of movement, the average distances traveled by granule cells during the tangential phase of their migration will be over 220 $\mu \mathrm{m}$, although individual cells may have a considerable longer trajectory. Furthermore, studies with ${ }^{3} \mathrm{H}$-thymidine indicate that the transit time of the postmitotic granule cells in the EGL increases during early postnatal development (Altman, 1972; Rakic, 1973, 1985), suggesting that late-generated granule cells move farther from the site of their birthplace during the tangential migration in the EGL than the early-generated granule cells.

Change in cell position, from the middle to the bottom level and then to the EGL-ML border, appears to be attributable to passive displacement as suggested from the electron microscopic reconstructions (Rakic, 1971). Because granule cell precursors divide approximately every $20 \mathrm{hr}$ within the top two levels of the EGL (Fujita et al., 1966; Fujita, 1967), the surface of the EGL expands rapidly outward. Moreover, as the cell soma leaves the territory of the EGL and their original horizontal processes transform into parallel fibers, the ML increases in thickness, and the EGL-ML border shifts toward the pial surface. Therefore, tangentially migrating granule cells situated at the middle level of the EGL

$\leftarrow$

Granule cells that underwent final cell division in the same area at the top level of the EGL may settle in different compartments in the IGL. For example, green granule cells may be instructed to enter a green compartment, whereas red granule cells may be instructed to enter a red compartment. Furthermore, postmitotic granule cells located in the left or right side of the hemisphere tend to migrate toward the midline region, whereas the cells located in the midline region do not exhibit a preference in the movement direction between the left and right side. 
relocate to the EGL-ML border within $24 \mathrm{hr}$ without undergoing an active downward movement, as illustrated in Figure $11 \mathrm{~A}$.

Although the cellular substrate responsible for the guidance of tangential cell migration in the EGL has not been experimentally established, it was suggested that the basic cellular mechanism may be similar to those involved in tangential movement of immature neurons in the medulla and the pons that are mediated by homotypic interactions between migrating neurons and neurites of the previously generated neurons (Rakic, 1985, 1990; Ono and Kawamura, 1989, 1990). In support of this hypothesis, it was reported that, in the microexplant cultures, granule cells move along the bundles of parallel fibers formed by previously generated granule cells (Nagata and Nakatsuji, 1990; Komuro and Rakic, 1996). This mode of granule cell movement may be similar to tangential migration of neuronal precursors from the telencephalic subventricular zone to the olfactory bulb, which occurs via chain migration and without the guidance of radial glia or axonal processes (Wichterle et al., 1997). However, an alternative possibility that cannot be excluded is that the tangential movement of granule cells may be guided by heterotypic gliophilic interactions at multiple glancing contacts with the vertically oriented Bergmann glial processes. This has been suggested for the tangentially migrating cortical neurons in the embryonic cerebrum (Rakic et al., 1974; O'Rourke et al., 1997). Furthermore, it might be possible that near the EGL-ML border the descending processes of tangentially migrating granule cells interact repulsively with the Purkinje cell dendrites because it was reported that repulsive interactions between ephrin-B1 on migrating granule cells and EphA4 on dendrites of Purkinje cells may determine the migratory pathway of granule cells in the ML of embryonic chick cerebellum (Karam et al., 2000).

Molecular mechanisms orchestrating the behavior of postmitotic granule cells in the EGL are also not well understood. It has been suggested that directionality of migration may depend on the extracellular matrix molecules localized on the ambient substrates (Fishell and Hatten, 1991; Rivas and Hatten, 1995), as it does in other systems (Rakic et al., 1994; Bronner-Fraser, 1995; Anton et al., 1999). Indeed, a variety of extracellular matrix molecules are expressed in the EGL (Chuong, 1990), and dissociated granule cells have been shown to migrate predominantly on the extracellular matrix molecules in the absence of either glial or axonal processes (Liesi, 1992; Fishman and Hatten, 1993). The molecules from the Netrin family have been shown to be involved in directing tangential migration in the EGL (Alcantara et al., 2000). In contrast, initiation of radial migration may depend critically on neuron-glia cell adhesion molecules (Ng-CAM) because the application of $\mathrm{Ng}-\mathrm{CAM}$ antibody inhibits the relocation of ${ }^{3} \mathrm{H}$-thymidine-labeled granule cells from the EGL to the ML (Chuong et al., 1987) but does not affect the granule cell migration along the glial processes in dissociating cultures (Edmondson et al., 1988).

The results reviewed above suggest that tangential and radial migration of the granule cells may depend on different signals emanating from the local substrates. However, intrinsic programs may also be involved in the determination of cell fate and in control of its migratory behavior in the EGL (Jankovski et al., 1996). In the microexplant cultures, for example, granule cells first migrate radially along the bundles of their neurites, and then, the cells abruptly change their orientation by $90^{\circ}$ and begin to translocate their nucleus within the newly developed neurite without any contact with glial cells (Nakatsuji and Nagata, 1989; Nagata and Nakatsuji, 1990). This suggests that changes in the direction of cell migration may be governed by intrinsic signals and the arrangement of the cytoskeleton (Rakic et al., 1996). Finally, it was reported that migrating granule cells express several genes at specific points along their pathway and that some of these genes encode for the specific receptors activated by the cell adhesion molecules (Kuhar et al., 1993; Hatten and Heintz, 1995; Hatten et al., 1997). Therefore, systematically alternating gene expression during the tangential migration of granule cells, combined with signals originating from the cellular elements of the EGL, may function as modulators of cell shape and their migratory behavior.

Does the tangential migration of postmitotic granule cells contribute to the allocation of granule cells across the various functional compartments of the cerebellar hemispheres? The developing cerebellum expresses distinct parasagittal, stripe-like compartments oriented in the anteroposterior direction (A-P compartments) that are dramatically revealed by the expression of specific genes and molecules (Hawkes and Leclerc 1987) (for review, see Herrup and Kuemerle, 1997; Ozol et al., 1999). Cellular organization is different in each parasagittal compartment, which contains a unique set of Purkinje cell phenotypes that can generate molecules that attract or repel migrating granule cells. The fact that most granule cells travel tangentially, perpendicular to the orientation of these parasagittal compartments, indicates that neurons may be instructed to enter a given compartment before initiation of their radial migration, as schematically shown in Figure $11 B$. It was suggested that appropriate allocation of the species-specific number of granule cells per Purkinje cell is orchestrated by signals emanating from their dendrites (Zecevic and Rakic, 1978), which may have attracting and/or repulsive properties (Alcantara et al., 2000). In the developing forebrain, immature neurons destined for the radial columns or layers of the cerebral cortex seem to be specified in the proliferative ventricular zone, before the initiation of their radial migration (Rakic, 1988; McConnell and Kaznowski, 1991, 1995). It is possible that the granule cells of the cerebellum are also specified to settle in a given A-P compartment similar to the formation of the protomap in the developing forebrain (for review, see Rubenstein and Rakic, 1999). However, it is unclear whether postmitotic granule cells cross A-P compartment boundaries during their tangential migration in the EGL before settling in a given A-P compartment, because each A-P compartment varies in position, as well as width, and are overlapping each other (Herrup and Kuemerle, 1997). It may be significant that radial migration of granule cells occur predominantly in the restricted pathways (named granule cell raphes) that are connecting the EGL and IGL (Lin and Cepko, 1998). The existence of granule cell raphes suggests that postmitotic granule cells may migrate tangentially until they reach the position of granule cell raphes in the EGL. Although granule cell raphes have not been identified in mice, tangentially migrating granule cells may start their radial migration in response to localized environmental cues. The combined use of acute slice preparations and confocal microscopy allows study of the role of various molecules and receptors in tangential cell movement in the natural cellular milieu.

\section{REFERENCES}

Alcantara S, Ruiz M, De Castro F, Soriano E, Sotelo C (2000) Netrin 1 acts as an attractive or as a repulsive cue for distinct migrating neurons during the development of the cerebellar system. Development 127:1359-1372.

Altman J (1972) Postnatal development of the cerebellar cortex in the rat. I. The external germinal layer and the transitional molecular layer. J Comp Neurol 145:353-398. 
Anton E, Kreidberg JA, Rakic P (1999) Distinct function of $\alpha_{3}$ and $\alpha_{\mathrm{V}}$ integrin receptors in neuronal migration and laminar organization of the cerebral cortex. Neuron 22:277-289.

Bronner-Fraser M (1995) Patterning of the vertebrate neural crest. Perspect Dev Neurobiol 3:53-62.

Chuong CM (1990) Differential roles of multiple adhesion molecules in cell migration: granule cell migration in cerebellum. Experientia 46:892-899.

Chuong CM, Crossin KL, Edelman GM (1987) Sequential expression and differential function of multiple adhesion molecules during the formation of cerebellar cortical layers. J Cell Biol 104:331-342.

Edmondson JC, Liem RK, Kuster JE, Hatten ME (1988) Astrotactin, a novel cell surface antigen that mediates neuron-glia interactions in cerebellar microcultures. J Cell Biol 106:505-517.

Fishell G, Hatten ME (1991) Astrotactin provides a receptor system for CNS neuronal migration. Development 113:755-765.

Fishman RB, Hatten ME (1993) Multiple receptor systems promote CNS neuronal migration. J Neurosci 13:3485-3495.

Fujita S (1967) Quantitative analysis of cell proliferation and differentiation in the cortex of the postnatal mouse cerebellum. J Cell Biol 32:277-287.

Fujita S, Shimada M, Nakamura T (1966) $\mathrm{H}^{3}$-thymidine autoradiographic studies on the cell proliferation and differentiation in the external and the internal granular layers of the mouse cerebellum. J Comp Neurol 128:191-208.

Hatten ME, Heintz N (1995) Mechanisms of neural patterning and specification in the developing cerebellum. Annu Rev Neurosci 18:385-408.

Hatten ME, Mason CA (1990) Mechanisms of glial-guided neuronal migration in vitro and in vivo. Experientia 46:907-916.

Hatten ME, Alder J, Zimmerman K, Heinntz N (1997) Genes involved in cerebellar cell specification and differentiation. Curr Opin Neurobiol 7:40-47.

Hawkes R, Leclerc N (1987) Antigenic map of the rat cerebellar cortex: the distribution of parasagittal bands as revealed by monoclonal antiPurkinje cell antibody mabq113. J Comp Neurol 256:29-41.

Herrup K, Kuemerle B (1997) The compartmentalization of the cerebellum. Annu Rev Neurosci 20:61-90.

His W (1890) Entwicklung des menschlichen Rautenhirns von Ende des ersten bis zum Beginn des dritten Monats. I Verlangertes Mark Abh Math Phy Cl Kgl Sachs Ges Wiss 29:1-74.

Honig ME, Hume CA (1986) Fluorescent carbocyanine dyes allow living neurons of identified origin to be studied in long-term cultures. J Cell Biol 103:171-187.

Jankovski A, Rosi F, Sotelo C (1996) Neuronal precursors in the postnatal mouse cerebellum are fully committed cells: evidence from heterochronic transplantations. Eur J Neurosci 8:2308-2319.

Karam SD, Burrows RC, Logan C, Koblar S, Pasquale EB, Bothwell M (2000) Eph receptors and ephrins in the developing chick cerebellum: relationship to sagittal patterning and granule cell migration. J Neurosci 20: 6488-6500.

Komuro H, Rakic P (1992) Selective role of N-type calcium channels in neuronal migration. Science 257:806-809.

Komuro H, Rakic P (1993) Modulation of neuronal migration by NMDA receptors. Science 260:95-97.

Komuro H, Rakic P (1995) Dynamics of granule cell migration: a confocal microscopic study in acute cerebellar slice preparations. J Neurosci 15:1110-1120.

Komuro H, Rakic P (1996) Intracellular $\mathrm{Ca}^{2+}$ fluctuations modulate the rate of neuronal migration. Neuron 17:275-285.

Komuro H, Rakic P (1998a) Distinct modes of neuronal migration in different domains of developing cerebellar cortex. J Neurosci 18:1478-1490

Komuro H, Rakic P (1998b) Orchestration of neuronal migration by activity of ion channels, neurotransmitter receptors, and intracellular $\mathrm{Ca}^{2+}$ fluctuations. J Neurobiol 37:110-130.

Komuro H, Rakic P (1999) In vitro analysis of signal mechanisms involved in neuronal migration. In: The neuron in tissue culture (Haynes LW, ed), pp 57-69. New York: Wiley.

Kuhar SG, Feng L, Vidan S, Ross ME, Hatten ME, Heintz N (1993) Changing patterns of gene expression define four stages of cerebellar granule neuron differentiation. Development 117:97-104.

Kuhn HG, Dickinson-Anson H, Gage FH (1996) Neurogenesis in the dentate gyrus of the adult rat: age-related decrease of neuronal progenitor proliferation. J Neurosci 16:2027-2033.
Liesi P (1992) Neuronal migration on laminin involves neuronal contact formation followed by nuclear movement inside a preformed process. Exp Neurol 117:103-113.

Lin JC, Cepko CL (1998) Granule cell raphes and parasagittal domains of Purkinje cells: complementary patterns in the developing chick cerebellum. J Neurosci 18:9342-9353.

McConnell SK, Kaznowski CE (1991) Cell cycle dependence of laminar determination in developing neocortex. Science 254:282-285.

Miale IL, Sidman RL (1961) An autoradiographic analysis of histogenesis in the mouse cerebellum. Exp Neurol 4:277-296.

Nagata I, Nakatsuji N (1990) Granule cell behavior on laminin in cerebellar microexplant cultures. Dev Brain Res 52:63-73.

Nakatsuji N, Nagata I (1989) Paradoxical perpendicular contact guidance displayed by mouse cerebellar granule cell neurons in vitro. Development 106:441-447.

Ono K, Kawamura K (1989) Migration of immature neurons along tangentially oriented fibers in the subpial part of the fetal mouse medulla oblongata. Exp Brain Res 78:190-201.

Ono K, Kawamura K (1990) Mode of neuronal migration in the pontine stream of fetal mice. Anat Embryol 182:11-19.

O'Rourke NA, Chenn A, McConnell SK (1997) Postmitotic neurons migrate tangentially in the cortical ventricular zone. Development 124:997-1005.

Ozol K, Hayden JM, Oberdick J, Hawkes R (1999) Transverse zones in the vermis of the mouse cerebellum. J Comp Neurtol 12:95-111.

Rakic P (1971) Neuron-glia relationship during granule cell migration in developing cerebellar cortex. A golgi and electron microscopic study in Macacus rhesus. J Comp Neurol 141:283-312.

Rakic P (1972) Extrinsic cytological determinants of basket and stellate cell dendritic pattern in cerebellar molecular layer. J Comp Neurol 146: 335-354.

Rakic P (1973) Kinetics of proliferation and latency between final cell division and onset of differentiation of cerebellar stellate and basket neurons. J Comp Neurol 147:523-546.

Rakic P (1981) Neuron-glial interaction during brain development. Trends Neurosci 4:184-187.

Rakic P (1985) Mechanisms of neuronal migration in developing cerebellar cortex. In: Molecular basis of neural development (Edelman GE, Cowan WM, Gall E, eds), pp 139-160. New York: Wiley.

Rakic P (1988) Specification of cerebral cortical areas. Science 241:170176.

Rakic P (1990) Principles of neuronal cell migration. Experientia 46:882-891.

Rakic P, Komuro H (1995) The role of receptor/channel activity in neuronal cell migration. J Neurobiol 26:299-315.

Rakic P, Stensaas LJ, Sayre EP, Sidman RL (1974) Computer-aided three-dimensional reconstruction and quantitative analysis of cells from serial electronmicroscopic montages of fetal monkey brain. Nature 250: 31-34.

Rakic P, Cameron RS, Komuro H (1994) Recognition, adhesion, transmembrane signaling and cell motility in guided neuronal migration. Curr Opin Neurobiol 4:63-69.

Rakic P, Knyihar-Csillik E, Csillik B (1996) Polarity of microtubule assembly during neuronal migration. Proc Natl Acad Sci USA 93:92189222.

Ramon y Cajal S (1911) Histologie du System Nerveux de l'Homme et des Vertebres, Vol 2. Paris: Malonine.

Rivas RJ, Hatten ME (1995) Motility and cytoskeletal organization of migrating cerebellar granule neurons. J Neurosci 15:981-989.

Rubenstein JLR, Rakic P (1999) Genetic control of cortical development. Cereb Cortex 9:521-523.

Ryder EF, Cepko CL (1994) Migration patterns of clonally related granule cells and their progenitors in the developing chick cerebellum. Neuron 12:1011-1029.

Sidman R, Rakic P (1982) Development of the human central nervous system. In: Histology and histopathology of the nervous system (Haymaker W, Adams RD, eds), pp 3-145. Springfield, IL: Thomas.

Wichterle H, Garcia-Verdugo JM, Alvarez-Buylla A (1997) Direct evidence for homotypic, glia-independent neuronal migration. Neuron 18:779-791.

Zecevic N, Rakic P (1976) Differentiation of Purkinje cells and their relationship to other components of developing cerebellar cortex in man. J Comp Neurol 167:27-48. 